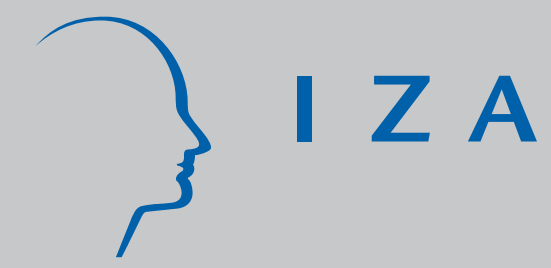

IZA DP No. 202

Gender Wage Differentials in a Competitive Labor Market: The Household Interaction Effect

Patrick Francois

J an C. van Ours

September 2000 


\title{
Gender Wage Differentials in a Competitive Labor Market: The Household Interaction Effect
}

\author{
Patrick Francois \\ CentER, Department of Economics, Tilburg University
}

Jan C. van Ours

CentER, Department of Economics, Tilburg University, CEPR, Institute for Labor Studies (OSA) and IZA, Bonn

Discussion Paper No. 202

September 2000

\author{
IZA \\ P.O. Box 7240 \\ D-53072 Bonn \\ Germany \\ Tel.: +49-228-3894-0 \\ Fax: +49-228-3894-210 \\ Email: iza@iza.org
}

This Discussion Paper is issued within the framework of IZA's research area The Future of Work. Any opinions expressed here are those of the author(s) and not those of the institute. Research disseminated by IZA may include views on policy, but the institute itself takes no institutional policy positions.

The Institute for the Study of Labor (IZA) in Bonn is a local and virtual international research center and a place of communication between science, politics and business. IZA is an independent, nonprofit limited liability company (Gesellschaft mit beschränkter Haftung) supported by the Deutsche Post AG. The center is associated with the University of Bonn and offers a stimulating research environment through its research networks, research support, and visitors and doctoral programs. IZA engages in (i) original and internationally competitive research in all fields of labor economics, (ii) development of policy concepts, and (iii) dissemination of research results and concepts to the interested public. The current research program deals with (1) mobility and flexibility of labor markets, (2) internationalization of labor markets and European integration, (3) the welfare state and labor markets, (4) labor markets in transition, (5) the future of work, (6) project evaluation and (7) general labor economics.

IZA Discussion Papers often represent preliminary work and are circulated to encourage discussion. Citation of such a paper should account for its provisional character. 
IZA Discussion Paper No. 202

September 2000

\section{ABSTRACT \\ Gender Wage Differentials in a Competitive Labor Market: The Household Interaction Effect ${ }^{*}$}

We present a theoretical explanation of the gender wage gap which turns on the interaction between men and women in households. In equilibria where men are over-represented in fulltime work, we show that firms rationally choose to hire women only at strictly lower wages than men. The model developed predicts a gap even controlling for education, occupation and industry of workers and does so in a competitive labor market where there exist no inherent gender differences. We test our theory using CPS data over the period 1979-98 and find it is strongly supported by the data.

JEL Classification: J71, J41, J16

Keywords: Gender discrimination, household models, wage gap

Jan C. van Ours

CentER,

Tilburg University,

P.O. Box 90153,

5000 LE Tilburg,

The Netherlands

Tel.: +31-13-4662316

Fax: +31-13-4663042

Email: vanours@kub.nl

\footnotetext{
* We thank, without implicating, Siwan Anderson and Michele Piccione for preliminary discussions of this work and Charlie Beach, Chris Ferrall, David Green, Alan Gregory, Joanne Roberts and Jano Zabojnik for comments and Joost Lebens for excellent research assistance. Thanks also to seminar participants at McMaster, University of Melbourne, Queen's University, University of Sydney, University of New South Wales, University of Tilburg, Birkbeck College London, Milan EALE Meetings and Saarbrucken University. The Social Sciences and Humanities Research Council of Canada provided financial support. Remaining errors are our own.
} 


\section{Introduction}

This paper develops and empirically assesses a theoretical approach to explaining gender discrimination based on the household. Rational pro..t maximizing employers who face a moral hazard problem in production, are shown to ..nd it optimal to pay women lower wages than they would pay to otherwise equivalent men. The explanation derives from the fact that individuals tend to form households with members of the opposite sex, and that, by their nature, households require services that cannot be adequately substituted with services purchased from the market. Individuals whose spouses are able to undertake the bulk of household work are freer to devote more of their own exort to their jobs, and consequently make better employees. We term this exect of a stay at home spouse on a worker's productivity the "household interaction exect". A $n$ implication of it is that, since individuals with stay at home spouses are more productive workers, competition in the market should raise their wages above those paid to workers without such spouses. However, since the current (or future) occupation of a person's current (or future) spouse is not publicly known, nor easy to credibly signal, employers condition on the likelihood of an employee having such a spouse when estimating the worker's market value. A critical conditioning variable is the employee's gender, as well as the usual human capital variables such as education. The strength of gender's exect is greatest for those individuals about whose household least can be inferred (i.e. the young with little work history), and is also strongest in those regions where participation rates vary greatly by gender. Thus in labor markets where few women are employed relative to men, the household interaction exect should be large, since in such places the probability of a man having a stay at home spouse is much higher than a woman's so that the theory predicts a relatively large gender gap. In contrast, where gender participation rates are close, the household interaction exect will not vary greatly by gender and the gender gap should be smaller.

The paper's empirical estimates utilize the variation in participation rates, across US states and years in CPS data from 1979-98, to determine the empirical relevance of this household interaction exect. The data supports the existence of such an exect which, due to its variation with state level participation rates, is easy to disentangle from the more traditional explanations for gender dimerences.

The present theory contrasts with the overwhelming majority of previous explanations of the gender gap by starting from a position of ex ante gender symmetry across the sexes. ${ }^{1}$. From a theoretical perspective, the paper is not the ..rst to suggest a link between household composition

\footnotetext{
${ }^{1}$ B ecker (1971) assumes an exogenous preference for men over women on either the part of employers, customers or co-workers. E arly statistical theories of discrimination assumed dixerences in the quality of productivity signals by gender, see Phelps (1973). Similarly, M ilgrom and Oster's (1987) invisibility hypothesis assumed that women's productivity is, for exogenous reasons, more diф cult to infer than men's. For a fuller discussion of early theoretical work see Cain (1986).
} 
and gender wage dixerentials. P revious work by A nderson and Francois (1997), Francois (1998b), Engineer and Welling (1997) and K awaguchi (1997), have all demonstrated that a dixerential can arise when women are more likely to have a partner who also has a job. However, unlike these previous theories based on household composition, the model here is the ..rst to generate gender wage dixerences within both occupations and industries, and it is the ..rst to theoretically establish a link between aggregate participation rates and gender wage dixerences. ${ }^{2}$ From a modelling perspective, this is a cumbersome exercise, since the combination of incentive compatibility conditions for workers and market clearing conditions for ..rms, renders the characterization of equilibrium far from straightforward. A contribution of this paper is thus in solving a model with closed form solutions that yields robust, testable implications. From an empirical point of view, the paper is, to our knowledge, the ..rst to test for and empirically estimate the magnitude of such a household interaction exect.

We view as a strength of the theory developed here that it takes as its starting point complete ex ante gender equality. This is not to deny the possibility of exogenous gender dixerences in say attitudes to, or aptitudes for, child-rearing, or, more directly, exogenous dixerences in productivity. Our approach here is to take an agnostic position on these other factors and allow for them in our empirical work. Since there are already a number of existing theories that can explain gender discrimination by positing exogenous dixerences, we allow for these other factors to enter in our estimating equation by measuring what we call the "classical wage gap". We do not model these exects directly in our theoretical work, although these could be appended, at the cost of some complexity, without mitigating the household interaction exect. We are, however, careful in the empirical work to identify only that part of the variation in wages which would not be predicted by these previous theories. Although, from a purely theoretical perspective, the complete ex ante symmetry of male and female characteristics implies that discrimination could equally well favor men, the theory predicts that the gender with the greatest full-time employment will have higher wages due to the household interaction exect. Thus, even though, by symmetry, there always exist equilibria in which women are paid higher than men, the data show that the necessary pre-conditions of such equilibria, over-representation of females, are not likely.

The results here weigh in against an almost persuasive view, recently argued by Darity and Mason (1998), that neoclassical economics is unable to provide convincing explanations of discrimination without assuming some sort of productive de..ciency in the group experiencing the discrimination. Their reasoning is that, without productivity dixerences between men and women, such dixerences in economic outcomes should not persist when hiring is undertaken by competitive..rms. Here, in contrast, the reason women are paid less is because fewer women, in aggregate, have good jobs. The theory developed here thus satis..es the dictates of competitive theory but,

\footnotetext{
${ }^{2}$ P revious theoretical explanations that start from ex ante gender symmetry are able to generate occupational exclusion, i.e. men getting some jobs and women others, but not a within occupation gender gap.
} 
at the same time, shows the source of female productive de.ciency to be ..rms' own actions: men and women do dixer in expected values, but only because of the equilibrium actions of ..rms.

The paper proceeds as follows: A formal model is developed in Section 2 generating testable empirical implications that are not suggested by previous theories of discrimination. This is tested using CPS data in section 3. Section 4 brieły concludes.

\section{The Model}

\subsection{Dual labor market setting}

The population is of size 1 and there is measure $\frac{1}{2}$ of each gender. All households are composed of two individuals, one of each sex, we discuss the inclusion of single individuals into the model later. Individuals form households with members of the opposite sex randomly and remain in the household until death. All individuals are in either one of two possible employment states: either in a full-time job, or not in a full-time job. For simplicity we treat all individuals not in full-time work equivalently, be they in household production, casual work, part-time work, fully unemployed, disabled or non-participating. ${ }^{3}$ There are an exogenous number, $\mathrm{N}<1$; ..rms, each requiring one full time worker, so that there are at least 1 i $\mathrm{N}$ individuals not in full-time work each period. ${ }^{4} \mathrm{~N}$ ot all individuals have the requisite skills, background or quali..cations required to perform in full time jobs. The proportion of males able to do so is denoted $q^{m}<1$ and correspondingly it is $q^{f}<1$ for females. It is assumed that an individual who is quali..ed to perform in a full-time job is able to costlessly demonstrate their quali..cations to a prospective employer. Unquali..ed individuals produce no output in jobs. To preserve ex ante gender symmetry we will assume that $q^{m}=q^{f}=q$ in what follows. ${ }^{5}$

The economy is not constrained by the number of quali..ed individuals in aggregate,

$$
\frac{q}{2}+\frac{q}{2}=q>N \text { : }
$$

However, in order to rule out uninteresting equilibria in which all jobs are obtained by one sex, and the other stays at home, we assume that there are more full-time jobs than quali..ed members of either sex:

$$
\frac{\mathrm{q}}{2}<\mathrm{N}:
$$

Time is discrete, and individuals survive for another period with probability $p 2(0 ; 1)$. For simplicity we assume no discounting since the term p is su $\$$ cient to lower the valuation of future

\footnotetext{
${ }^{3} \mathrm{~A}$ dding these additional states considerably complicates the analysis but will not axect the main results provided that it remains the case that, in any of these states, individuals expend less exort at work than workers in full-time employment.

${ }^{4}$ T he analysis is thus partial equilibrium, since we do not allow for ..rm entry and exit. A fter the main results are established we discuss the consequences of allowing for ..rm entry endogenously.

${ }^{5}$ It will be seen, however, that this symmetry assumption is not necessary for the existence of a gender gap.
} 
returns. It also proves useful in generating labor market turnover, as will be seen subsequently. When individuals die, population turnover is immediate; identical individuals take their place so that both population size and composition remain constant. For simplicity again, the term $p$ operates at the level of households so that the structure of households in the economy is also stationary.

\subsection{Households}

A central assumption made here is that the disutility of full-time work experienced by each household member is higher when both household members are working than when only one works. This is a reasonable assumption when households require the performance of certain tasks that cannot be substituted by purchases from the outside market. The best example of such tasks would be child-rearing, but the substitutability of other services may also be poor. ${ }^{6}$ In that case, these tasks must be provided by at least one household member, and their performance raises the disutility of exerting exort at work, for the usual reasons of diminishing marginal returns to leisure.

We model the household's utility as collective, so that each individual's utility can be represented by the household's, and is thus a function of aggregate household variables only. This is without loss of generality, since the potential for specialization and gains from trade when treating household members separately, would also give rise to qualitatively similar results, as in Francois (1998b). Within period utility for a couple, $i$ and $j$, is given by

$$
U=w_{i}+w_{j} \text { i } c\left(e_{i}+e_{j}\right) \text {; }
$$

where $\mathrm{w}$ denotes wages paid and e denotes person i $Q_{s}$ exort exerted: The function $\mathrm{c}(\phi)$ is twice continuously dixerentiable, increasing and convex, to refect the increasing disutility to work and $c(0)=0 .{ }^{7}$

\subsection{Production}

Each one of the measure $\mathrm{N}$ employers requires one quali..ed worker for production, and quali... cations are observable. The type of contracts that can be enforced between an employer and a worker are limited by the veri..ability of the tasks performed. We assume that exort contributed to tasks at work is not observable nor contractible but can be inferred by employers after a delay

\footnotetext{
${ }^{6}$ In Francois (1998b) the sources of this are more carefully explored. It is shown there that the disutility of essential housework rises with increased external work even if it is assumed that households are able to purchase services externally, and individuals have independent utility functions.

${ }^{7} T$ he chosen form of household structure is not essential for the paper's main results and is used for ease of exposition only. Francois (1998a) develops an analogous model for a generalized household structure in which individuals are allowed to act independently or collectively, and for a generalized concave utility function, where all qualitative results are preserved. A critical assumption that is needed, however, is seperability between consumption and work components of utility. This is standard in eф ciency wage models.
} 
of one period. Thus, by assumption, contracts conditioning worker payment on exort or output will not be entered into. The technology of full-time work is such that worker exort, e; is essential. There exists a critical level of exort, e; such that:

$$
\begin{aligned}
& \mathrm{e}<\text { eyields output }=0 \\
& \mathrm{e}, \quad \text { eyields output }=\mathrm{y}:
\end{aligned}
$$

In addition, young workers must work harder to learn the skills required in their occupation. This learning cost is denoted in income terms as an amount $k$, which is incurred by individuals in their ..rst period of work. It is incurred independently of exort choice and cannot be avoided once employed. When skills are learned they do not have to be re-learned, so this cost only occurs in the ..rst period of employment. ${ }^{8}$

For simplicity we normalize the exort exerted and the wages received by unemployed individuals to 0 .

It is eф cient for all good jobs to be ..lled by one quali..ed worker from each household. That is:

$$
\begin{aligned}
& y \text { i } c(e) i k+\frac{p}{1 ; p}(y i c(e))>0 \\
& y>c(e)+(1 ; p) k:
\end{aligned}
$$

\subsection{Timing and information}

The timing of events is as follows: Each period a fraction $p$ of new households come into existence to replace the ones that died. Each household member has a spouse who may, or may not, be quali..ed. Since quali..cations persist through life, unquali..ed individuals will always be unemployed. Quali..ed individuals, in contrast, can be productive workers. In order to obtain work they enter the hiring pool in their ..rst period of life. We call this period the "young" period of life, individuals surviving for more than one period are referred to as "old". It will be seen that only "young" individuals are hired from the hiring pool, in equilibrium, but it is possible for even the old to apply for a job. Employers with vacancies come to the hiring pool and can observe only a candidate's quali..cations, gender and age. Importantly they cannot observe the

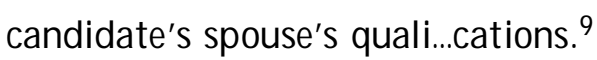

Since exort is not observable and output is non-contractible, there is a moral hazard problem in production. However, the possibility of repeated interaction between a worker and ..rm allows for this moral hazard to be solved by a standard et ciency wage contract. The existence of such contracts, in equilibrium, is formally established in the main proposition, but for now we

\footnotetext{
${ }^{8} \mathrm{~T}$ he technically convenient role of these learning costs in the model is to ensure wages are positive in all periods.

${ }^{9} \mathrm{~N}$ ote that this is consistent with the assumption that an employer does not have relevant information about an employee's spouse. Since, in equilibrium, it will be seen that employees always have incentive to claim their spouse is unquali..ed, employers cannot trust employees' announcements.
} 
describe the actions which correspond to such a self-enforcing contract: E mployers requiring an employee come to the hiring pool and call a wage, or wages at which they would be willing to hire an individual. These may vary by gender and age, for example $w^{f}$ or $w^{m}$; for women and men respectively. If they receive more than one applicant at their called wages, they choose one randomly. The agreed upon wage is paid to employees up front, and paired employers and employees then undertake production together. At the end of the period, employers observe output and infer exort. If output equals zero, the employer dismisses the employee and all other employers see this has occurred. If output equals $y$; the individual is not dismissed, and this is also observed by other employers. Firms are free to compete amongst themselves for the services of workers by oxering wages at any stage. This sequence is summarized below:

\begin{tabular}{|c|c|c|c|c|c|c|c|c|c|c|}
\hline $\begin{array}{l}\text { Young quali..ed } \\
\text { worker enters } \\
\text { hiring pool }\end{array}$ & 1 & $\begin{array}{l}\text { Firms } \\
\text { call } \\
\text { wages } \\
\text { wi }^{i}\end{array}$ & ! & $\begin{array}{l}\text { Some } \\
\text { hired }\end{array}$ & ! & $\begin{array}{l}\text { If hired, } \\
\text { paid } w^{i} \text {; } \\
\text { exort } \\
\text { chosen - k }\end{array}$ & $!$ & $\begin{array}{l}\text { prob. } p \\
\text { live to } \\
\text { be old }\end{array}$ & ! & $\begin{array}{l}\text { if output=0 } \\
\text { dismissed, } \\
\text { if output=y } \\
\text { re-hired }\end{array}$ \\
\hline
\end{tabular}

\subsection{Incentive Compatibility Conditions}

For a meaningful equilibrium in which positive output is produced it is necessary that workers' incentive compatibility conditions hold. In an eф ciency wage type equilibrium, shirkers obtain a one period bene..t from shirking but are then dismissed and not re-hired in future. The wage bene..t of having such good jobs must therefore be high enough to exceed the gain from shirking. But the gain from shirking depends on one's spouse's job. Thus incentive compatibility conditions vary depending on whether one's spouse also has a job.

It will be established subsequently, that, when old, all working individuals receive the same wage. We thus denote this wage, wold. The wages of the young, however, can potentially vary by gender, so we denote these by $w^{m}$ and $w^{f}$ : We also restrict our attention to equilibria in which old individuals who are without work experience are never hired. ${ }^{10}$

Let $\mathrm{V}^{\mathrm{CD}}$ denote a person's state. This is the expected lifetime utility of a person who is either employed, $\mathrm{C}=\mathrm{E}$ or unemployed, $\mathrm{C}=\mathrm{U}$; and whose spouse denoted by the second superscript, is similarly either employed, $\mathrm{D}=\mathrm{E}$; or unemployed, $\mathrm{D}=\mathrm{U}$ : There are thus 4 possible states. The incentive compatibility condition for a young person of sex $i$ whose spouse, sex $j$; is employed is:

$$
w^{i}+w^{j} \text { i } 2 k_{i} c(2 e)+p V^{E E}, w^{i}+w^{j} i 2 k i c(e)+p V^{U E}:
$$

If working, i.e., the left hand side of (3), the worker remains employed provided he or she stays alive, probability p: If shirking, the right hand side, the worker bene.ts from lower exort but

\footnotetext{
${ }^{10}$ It will be seen that, in equilibrium, ..rms are indixerent between hiring old individuals without work experience and hiring young individuals. By focusing only on equilibria in which this indixerence is resolved in favour of the young, we considerably simplify calculation of value functions. W ithout this assumption qualitatively similar equilibria arise, though these are more complicated.
} 
transitions into a bad job with value $\mathrm{V}^{\mathrm{UE}}$ : Since, he or she never gets a good job again, the value of being in this state is:

$$
\begin{aligned}
V^{U E} & =w^{\text {old }} i c(e)+p V^{U E} \\
& \Rightarrow \quad V^{U E}=\frac{w^{\text {old }} i c(e)}{1 ; p}:
\end{aligned}
$$

Similarly, if the worker continues to not shirk in future, he or she will keep the job until death, that is:

$$
\begin{aligned}
V^{E E} & =2 w^{\text {old }} i c(2 \bar{e})+p V^{E E} \\
& \Rightarrow \quad V^{E E}=\frac{2 w^{\text {old }} i c(2 \bar{e})}{1 \text { i } p}
\end{aligned}
$$

Substituting these into ( 3 ) yields the incentive compatibility condition for a worker whose spouse also has a job:

$$
\frac{p}{1 i p}^{h} 2 w^{\text {old }} \text { i } c(2 \bar{e}){ }^{i} \text { i } c(2 \bar{e}), \frac{p}{1 i p}^{3} w^{\text {old }} \text { i } c(e) \text { i } c(\bar{e}) \text { : }
$$

Note that this condition does not depend on wages when young, but only the future wage that one will receive when old, wold; a point to which we return shortly.

The analysis is almost identical for a person with a stay at home spouse. Again, for person of sex $\mathrm{i}$ with spouse $\mathrm{j}$; the conditions are:

$$
\begin{aligned}
w^{i} i c(e)+p V^{E U} & , w^{i}+p V^{U U} \\
V^{U U} & =0 \\
V^{E U} & =\frac{w^{\text {old }} i c(e)}{1 i p}
\end{aligned}
$$

Once again the incentive compatibility condition only depends on the wage paid when old:

$$
\frac{p}{1 i p}{ }^{h} w^{\text {old }} \text { i } c(e) \text { i } c(e), 0 \text { : }
$$

These conditions imply the following:

Proposition 1 Binding incentive compatible wages are higher for individuals whose spouses have employment:

Proof: Immediate by contrasting incentive compatibility conditions for working and nonworking spouses and noting the convexity of $c(:): ¥$

The intuition for this is straightforward: if your spouse also has a good job your household's opportunity cost of work is high. Wages then need to be higher to ensure incentive compatibility. 
The relevant wage is not the current wage, since this is received whether shirking or not, but the wage received in future periods, wold; which is determined subsequently.

We now place a substantive restriction on the disutility of exort. In particular, we assume that the exort required when both household members have good jobs is prohibitively high:

A ssumption 1:

$$
c(2 \bar{e})>2 y:
$$

The assumption implies that households with both members in good jobs suxer so great a disutility to working that the optimal action is for one member to shirk. To see this, note that even if employees were paid the full value of output, $w=y$; they would still not be suc ciently compensated for the disutility of exort. It is a strong assumption and clearly not valid for all households in reality, we pause to discuss why it is reasonable here. The assumption renders it infeasible for both household members to pursue careers simultaneously. Households then may have both individuals accepting jobs when young, but (8) ensures one of them will give up this job by shirking. In reality, there is enough heterogeneity in real world labor markets to observe households where both household members pursue demanding careers. Allowing for this sort of heterogeneity here would complicate our analysis without modifying our results provided it is still the case that people with stay at home spouses are more likely to persist in their careers than people with spouses also working full-time. This greater likeliness of persisting at work with a stay at home spouse is the substantive assumption that is necessary here. Provided this holds, then the expected value of an employee with a stay at home spouse will exceed that of an employee whose spouse works. Assumption 1 simply takes this to an extreme by assuming that in all households only one individual will choose to pursue a career, i.e. not shirk.

\subsection{Expected value of an employee}

First consider the expected value of employing an old individual. Old individuals who are known not to have shirked in the ..rst period of their lives will be believed not to shirk in any subsequent period. This is because, if incentive compatibility held for them then, their spouse must not also have had a good job, or, if he or she did, the spouse shirked. In either case, since we focus on equilibria in which old individuals without work experience are not hired, that spouse will not obtain a job in future, so that the present old individual will continue to ..nd it optimal to contribute exort for every period that he or she stays in the labor market. Therefore, if we denote the one period value of hiring an old employee at wage $w^{\text {old }}$ by $E^{\text {old }}\left(w^{\text {old }}\right)$; it is given by:

$$
\mathrm{E}^{\text {old }}{ }^{3} \mathrm{w}^{\text {old }}=\mathrm{y}_{\mathrm{i}} \text { wold: }
$$

Now consider the expected value of hiring a young employee. Such individuals are hired from the hiring pool, they have no employment history and it is not possible for employers to 
accurately infer the likely occupation of their spouse. Since Assumption 1 ensures that incentive compatibility will not hold in households where both have good jobs, one person will shirk. We assume the shirker is chosen randomly from both household members. ${ }^{11}$

Let the probability of a man who is young obtaining a job be denoted $1 / 2$; correspondingly this is $1 / 2$ for women. ${ }^{12}$ The one period expected value of hiring a quali..ed man from the hiring pool at a wage $\mathrm{w}^{\mathrm{m}}$ is thus:

$$
E^{m}\left(w^{m}\right)={ }^{3} 1 i \frac{1}{2}\left(y i w^{m}\right)+1 / 2 \frac{1}{2}\left(y i w^{m}\right) i \frac{1}{2} w^{m} \text {; }
$$

since with probability ${ }^{i}{ }_{1}{ }_{i}{ }_{1 / 2}{ }^{\$}$ his spouse does not have a job, and with probability $1 / 2$ she does, so that there is then probability $\frac{1}{2}$ he shirks. The symmetric holds for females with $1 / 2$ replacing $1 / 2$ :

If we let \pm denote the proportion of jobs held by men in equilibrium, then male overrepresentation in good jobs is denoted by $\pm>\frac{1}{2}$ : It is useful to reexpress $1 / 2$ and $1 / 2$ in terms of \pm Since p people die each period, and the measure of jobs is $N$; there are $\mathrm{pN}$ new jobs available each period. There are also pq $>$ pN new quali..ed applicants in the pool. By de.nition we then have $\pm \mathrm{pN}$ new jobs obtained by men, and $(1 \mathrm{i} \sharp \mathrm{pN}$ new jobs obtained by women. Thus the probability of a quali.ed man obtaining a good job is $\frac{2+\mathbb{N}}{q}$; and similarly this probability is $\frac{2\left(1_{i} \pm N\right.}{q}$ for quali..ed females. Thus we can re-express (10) as:

$$
\begin{aligned}
E^{m}\left(w^{m}\right)= & (1 ; q)\left(y i w^{m}\right)+q \frac{(1 i \# N}{q}^{\mu} \frac{1}{2}\left(y i w^{m}\right) i \frac{1}{2} w^{m} \\
& +q 1 i \frac{(1 ; \# N}{q}\left(y i w^{m}\right) \\
\Rightarrow \quad & E^{m}\left(w^{m}\right)=(1 ; q)\left(y i w^{m}\right)+\left(1 ; \# N \frac{1}{2}\left(y i w^{m}\right) i \frac{1}{2} w^{m}\right. \\
& +\left(q i(1 ; \# N)\left(y i w^{m}\right):\right.
\end{aligned}
$$

In each of these expressions the three terms correspond to the three possible outcomes that can occur when hiring a quali..ed individual: the ..rst occurs when the individual does not have a quali..ed spouse, the third, when their quali..ed spouse does not ..nd work and the second when their quali..ed spouse has a job. The second expression shows the potential loss, which occurs with probability $\frac{1}{2}$, of paying a worker who does not perform. The expression further simpli..es to:

$$
E^{m}\left(w^{m}\right)=y i \quad w^{m} i \quad\left(1 ; \# N \frac{y}{2}\right.
$$

\footnotetext{
${ }^{11}$ It will be seen that, even if young individuals are paid dixerent wages by sex that the household's utility is unaxected by the identity of the shirker, so this assumption is valid.

${ }^{12}$ Since individuals who are young also have spouses who are young, and there is no assortative matching, the term $1 / 2$ also denotes the probability that a person of sex $i$ who is young has a spouse with a job. We discuss the implications of introducing assortative matching in the conclusions.
} 
Once again, an analogous expression is generated for females, $\mathrm{E}^{\mathrm{f}}{ }^{\mathrm{i}} \mathrm{w}^{\mathrm{f}}{ }^{\$}$ with \pm replacing $1_{\mathrm{i}} \pm$

$$
E^{f} w^{f}=y i w^{f} i \pm N \frac{y}{2}
$$

It can be seen directly from these expressions that, the higher is \pm the higher is the expected value of a young male employee, and the lower that of a young female employee. Intuitively, the higher the over-representation of males in good jobs, the lower is the likelihood that a male will have a spouse also in a good job and, correspondingly, the higher is the likelihood that a female will have a spouse also in a good job. Since this is positively correlated with shirking, females' expected values will be lower. If we impose the condition that the expected value of each individual employed must be equal, then we can solve explicitly for the wage dixerential as a function of \pm that is:

$$
\begin{aligned}
& E^{m}\left(w^{m}\right)=E^{f} w^{f} \\
& w^{m}=w^{f}+N y^{\prime} \pm_{i} \frac{1}{2}^{\text {ๆ }}
\end{aligned}
$$

\subsection{Equilibrium}

Although conditions (12) and (13) and correspondingly (14) are the reason for the gender gap here, it remains to show that wages satisfying these can comprise an equilibrium. In an equilibrium, ..rms cannot bene..t by deviating from the equilibrium wage schedule, workers cannot bene.t from changing their exort decisions, and the expectations ..rms have about the likelihood of each gender shirking must be consistent with those realized by workers' equilibrium actions. We now demonstrate that a wage dixerential consistent with conditions (12) and (13) and hence (14) constitutes an equilibrium. Since women and men are ex ante symmetric, if there exists an equilibrium in which men are over-represented ${ }^{i} \pm>\frac{1}{2}^{\dagger}$, there always also exists a symmetric one in which their roles are reversed. Here we focus exclusively on the equilibrium in which men are over-represented, since these are the most empirically relevant:.

Proposition 2 If the value of output in full-time work, y; is high enough, the following wages constitute an equilibrium:

$$
\begin{aligned}
w_{\alpha}^{\text {old }} & =c(e)+(1 ; \quad p) k+(1 ; \quad p) \pm \frac{N y}{2} \\
w_{\infty}^{f} & =c(e)+(1 ; \quad p) k i \quad p \pm \frac{N y}{2} \\
w_{\infty}^{m} & =c(e)+(1 ; \quad p) k+(2 \pm i \quad p \pm i \quad 1) \frac{N y}{2}
\end{aligned}
$$

In this equilibrium: (i) wages of young women are lower than wages of young men, with the dixerence given by (14) (ii) wages of old men and women are equal, (iii) all young quali..ed men 
obtain work, (iv) some quali..ed women do not obtain work (v) men of all ages are over-represented in full-time work.

\section{P roof in appendix 1.}

In equilibrium, men's over-representation in good jobs implies they receive a higher wage than women, point (i). But since some young men shirk, this is still lower than the wages they receive when older, furthermore it is lower than older female's wages which must, by competitive forces, equal those of older men, point (ii). The reason wages of females who stay in the labor market eventually catch up to their male counterparts is that their staying in the labor market allows employers to infer their commitment. The wage dixerential is explicitly given by (14) : Levels are also solved for by using the young females' binding participation constraints, but, since males' participation constraints do not bind, all young males obtain the opportunities to receive good jobs when young, some females, however, do not, points (iii) and (iv). Finally, more men obtain good jobs, and fewer leave the labor market, so they are over-represented in good jobs for each age cohort, point (v).

The model's outcomes are consistent with many components of the empirical record:

(i) men are over-represented in high paying occupations, Gunderson (1989) Reskin and Roos (1991),

(ii) though men are over-represented, there is still mixing of sexes within occupations, and averaging across occupations the gender wage gap favors men

(iii) even without ex ante dixerences between the sexes, women are more likely to leave their current job, Viscusi (1980), Blau and Ferber (1986), Osterman (1982), and more likely to exit the labor market, even controlling for education and experience, see B owlus (1997).

\subsection{Properties of the equilibrium}

In this gender gap equilibrium employers perceive the likelihood of women continuing in pursuit of careers to be lower than that of men, not, however, due to inherent gender dixerences, but rather because the proportion of men in good jobs exceeds that of women. This over-representation is depicted by the parameter $\pm A s \pm$ ! $\frac{1}{2}$; there is gender equality, and as \pm ! 1 women are more severely under-represented. Comparative static analysis of this equilibrium yields the model's predictions about variations in the gender gap with \pm

Corollary 3 In a wage gap equilibrium, the size of the wage gap is strictly increasing in the relative proportions of men to women in employment, \pm

Proof: Immediate from (14): 


\subsection{R obustness of the model}

Before empirically assessing the model we pause to consider the consequences of relaxing the model's main simplifying assumptions.

The analysis is partial equilibrium. That is, we have assumed throughout that the economy is not supply constrained by the aggregate number of skilled individuals and have treated the aggregate demand for labor as inelastic and exogenous. A more general framework with endogenous labor demand as a function of the wage (as in Shapiro and Stiglitz (1984)) will yield, in any el ciency wage equilibrium, excess supply of labor as we have assumed. This is because, with excess demand, wages are bid up until the demand disappears by ..rm exit. Note that this does not hold reciprocally for excess supply since incentive compatibility conditions force a lower bound on wages and rule out market clearing. Thus, our assumption of excess supply would arise endogenously in a general equilibrium model. Given the same pattern of entry, the characterization of equilibrium wages would be identical.

The introduction of single individuals will only axect results if these individuals are preferred to individuals who have spouses at home who are in good jobs. That is, if the bene.ts of being single, in terms of lower household time requirements, exceed the bene.ts of being married to someone who is not in a pressing job and can undertake much of the housework for you. If this were the case, then ..rms would strictly prefer to hire single individuals over married individuals. However, then the issue arises as to how ..rms can ensure that employees do in fact remain single. If it is costly to observe whether an individual who claims to be single, in fact remains single, then the considerations in the present paper again become important. In that case, though the probability of becoming married will not vary systematically by sex, ..rms will condition the costs of marriage (in terms of expected productivity) on a person's sex. In an economy where men have most of the good jobs, the probability of a man obtaining a spouse who is also in a good job is relatively low compared with women, and a dixerential in expected values will again emerge. However, it is important for the model that not too many individuals are single. Clearly, with all individuals single, discrimination cannot arise in this model because household considerations become irrelevant. However, even though recent decades have seen unprecedented increases in the number of people remaining single, these still constitute a minority, so the signi..cance of potential household interactions is likely to remain, see Popenoe (1993).

The model assumes no assortative matching of individuals, however assortative matching in the marriage market would imply that individuals in jobs are themselves more likely to have spouses in jobs. This raises the probability of an individual having a spouse who is also in a job in the hiring pool. However, since this axects both sexes symmetrically, rising proportionality for both men and women, it does not axect the relative valuations of men and women, and hence does not axect the qualitative results here. 
The shirking based eф ciency wage structure used here is not necessary for the model's results to persist. The critical aspect for the theory here is that an employee's departure is costly to the ..rm. Without costs, that is, if workers are paid their marginal products, ..rms will not mind workers leaving and will thus not wish to condition employment on likely household composition. The shirking based eф ciency wage model used here contains such costs, but this is not the unique theoretical way of doing so. The turnover based eф ciency wage models, for example as in B eaudry (1994), would yield qualitatively similar predictions about wage dixerentials, since there would again be a cost to employers from turnover. Thus, the shirking implication should not be seen as a robust qualitative feature of the discrimination examined here. Essential features are that these occupations require exort (so that total household work supplied is important) and that there is some cost to employers when employees choose to leave the labor market.

The model assumes that the probability of death, $1_{\mathrm{i}}$ p; operates at the household level, which is highly unrealistic. If instead, it operated on individuals then it would be possible for individuals to be made single, at least temporarily. Adding this extension doubles the number of states, and corresponding value functions, making the model intractable, so we have not been able to solve for the case of death probabilities which operate at the individual level. However, since, once again, the exect of such a change is symmetric across sexes it would seem unlikely to axect the model's qualitative outcomes.

Allowing individuals to be re-hired upon dismissal will tend to weaken the incentive compatibility conditions for women relative to those of men, thus lowering women's incentive compatible wages, in comparison with those of men. This was the avenue by which women and men could be paid equivalent wages within occupations in Bulow and Summers (1986). However, in the present model, the equilibrium wage dixerential is not determined by dixerences in incentive compatible wages but rather by dixerences in expected value of male and female employees. (R ecall that all that matters is that individuals with spouses in jobs have higher incentive compatible wages than those with spouses who do not work, which will continue to be true). Allowing the possibility of re-hiring individuals will lower incentive compatible wages for women relative to men, with the only possible exect of this, in equilibrium, being an increase in the magnitude of the gender gap, so that, qualitatively, the model's results are again unaxected.

We conclude that the model's qualitative implications, embodied in equations (15) ; (16) (17) and the Corollary, are robust to relaxation of the simplifying assumptions, and realistic extensions.

\section{Empirical analysis}

\subsection{Data}

According to the theory in the previous sections employers condition on the distribution of males/ females in the relevant labor market, that is the geographical segment of the labor market 
from which the employer is hiring. We assume this to be the state. In our empirical analysis we use CPS data to test the predictions from the theory. ${ }^{13}$ M ore speci..cally, we use data prepared by the NBER with extract of the ..les from 1979 to 1998. Here, we give a brief description of the data (see for details Feenberg (1999)). The NBER-extracts include individual data for about 30,000 individuals each month for 240 months. There are about 50 variables that relate to employment (hours worked, earnings, industry, occupation, education, and unionization), age, sex, race, ethnicity, geographical location et cetera. An adult at each household is asked to report on the activities of all other persons in the household. There is a record in the ..le for each adult person. ${ }^{14}$ Each household entering the CPS is administered 4 monthly interviews, then ignored for 8 months, then interviewed again for 4 more months. If the household moves, they are not followed. For every year in the CPS dataset households in months 4 and 8 have been asked their usual weekly earnings/usual weekly hours. The NBER-extract only contains information from these months 4 and 8. So, an individual appears only once in any ..le year, but may reappear in the following year. We are interested in the exect of changes in the proportion of men in high paying jobs on the gender wage gap at the state level. Since the proportions are not likely to change at a high frequency, from every year we only use March data. As indicated in the previous sections, we expect the gender gap to apply only to young individuals. Therefore, we further reduce our sample to individuals between ages 25 and 34 years. For these individuals Figure 1, solid line, plots the relative hourly wage of males over the period. As has already been well documented, see O'Neill and Polachek (1993), this relative wage declined over the period.

\subsection{Statistical model and estimates}

A s indicated above, we assume the relevant geographical labor market to be the state and investigate the relevance of our theory by using log-earnings regressions. The variable distinguishing our theory from previous ones is the employment share, \pm refecting the degree of male overrepresentation in the relevant labor market (state and year) which, in turn, axects relative wages through the household interaction exect. We identify the household interaction exect from crossstate variation over calendar time of the share of females in the labor market.

We estimate the share of males in full-time employment, $t_{s ; t}$ for state $s$ at year $t$, as follows:

$$
\pm_{s ; t}=0: 5 \propto \frac{\left.L_{s ; t}^{m} \neq L_{s ; t}^{m}+L_{s ; t}^{f}\right)}{\left.B_{s ; t}^{m} \neq B_{s ; t}^{m}+B_{s ; t}^{f}\right)}
$$

\footnotetext{
${ }^{13}$ CPS-data are limited in terms of information about individual workers concerning their ability, past labor market experience and family background characteristics. A Itonji and Blank (1999) discuss a sensitivity analysis in which they compare gender wage gap estimates based on CPS-data with estimates based on more informative data from the $\mathrm{N}$ ational Longitudinal Survey of Youth-data. They conclude that the lack of information in the CPS-data is not very relevant when studying gender wage gaps.

${ }^{14} \mathrm{~T}$ he universe is the adult non-institutional population. In the NBER-extracts all persons 16 years of age and over are included.
} 
where $L$ stands for employment, $B$ for the total number of individuals in the population between ages 25-34 in the sample, and the superscripts refer to male and female. Dividing through by the share of males in the population normalizes the employment share by controlling for sample size variations across states and times that dixer by gender. Multiplying by 0.5 makes this empirical de..nition of \pm the same as the one in the theoretical section. A veraging over the period, \pm has a mean of 0.607 and a standard deviation of 0.060 . Figure 1 , dashed line, plots the value of \pm by year (averaging across states) over the period. As is broadly consistent with the theory, \pm has fallen over the period, rełecting the greater inłux of females into full-time work, but still reł ects males' over-representation in full time work.

We base our estimates on a sample of 62,753 observations (see A ppendix 2 for details on the data). In our estimates we start by assuming that all the state speci..c ..xed dixerences in the gender wage gap might be related to dixerences in the male share in employment. Furthermore, we assume that nation-wide changes over time in the gender wage gap are also related to changes in the male share in employment. In the next subsection we investigate to what extent our results change if we explicitly allow for these state speci..c dixerences and trend-like changes in the gender wage gap. In the sensitivity analysis we present in the next subsection we also investigate to what extent our results apply to workers aged 35-44 and workers aged 45-54 years. Finally, we investigate to what extent the results we ..nd may be driven by reversed causality whereby the declining gender wage gap induced females to enter the labor market.

\subsubsection{Aggregate data}

We start with regressions based on aggregate information, that is, average wages of full-time male and female workers per state per year, so we have 2,040 observations (51 states, 20 year, males and females). We estimated the following relationship:

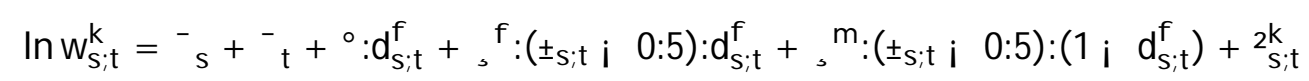

where $w$ is the hourly wage (averaged over all males or females within a state in a particular year) and $\mathrm{d}^{\mathrm{f}}$ a dummy variable with a value 1 for females and a value 0 for males. Furthermore, $\mathrm{k}$ is a superscript indicating whether the wage concerns males $(k=m)$ or females $(k=f),{ }^{-}{ }_{s}$ and ${ }^{-}{ }_{t}$ are the ..xed exects for state and calendar year. Finally, ${ }^{\circ}$ is the coec cient that represents the classical gender wage gap,,${ }^{f}(, m)$ is the coec cient that indicates to what extent female (male) wages are infuenced by the household interaction exect and ${ }^{2}$ is the error term. The coel cients are estimated using weighted least squares regression with the number of observations per group as weights. The estimation results are shown in Table 1.

The coed cient in the ..rst column of Table 1 indicates that, on average, over the period and the states, the wage gap between males and females is $21.4 \%$. The second column indicates that 
household interaction is axecting both the male wage and the female wages. The higher the share of males in employment the lower the wage of females and the higher the wage of males. According to the estimated coec cients the classical wage gap, the wage gap that would remain if the share of males in employment were equal to 0.5 , is now on average $14.7 \%$. Since the average share of males in employment is $60.7 \%$, female wages are reduced by $3.8 \%$-points and male wages are increased by $3.1 \%$-points. So, of the original wage gap of $21.4 \%, 6.9 \%$-points can be attributed to the household interaction exect. In other words, about one third of the wage gap between males and females can be explained by the household interaction exect. The third column shows the estimation results if we impose, ${ }^{f}=\mathrm{i}, \mathrm{m}=-$ : As indicated by the value of the F-statistic we cannot reject the hypothesis that both household interaction exects have the same size (in absolute terms).

The fourth column of Table 1 shows how the wage gap changed over the period of time we consider, because we include a trend in the wage gap. In 1979 the gender wage gap was 30.4\%, but on average every year the gap declined by 1.02\%-points. Over the period 1979-1998 the wage gap decreased by $18.4 \%$-points. Column ..ve shows that part of this decline can be explained by the household interaction exect. After introducing a gender-speci..c time trend the value of - decreases (in absolute terms), but is still signi..cantly dixerent from zero. Finally, column six shows that even after including state speci..c gender wage gaps we still ..nd a household interaction exect that is signi..cantly dixerent from zero. The result that household interaction is important seems to be quite robust.

\subsubsection{M icro data}

Next, we used the micro CPS-data to estimate wage regressions where the most extended is speci..ed as:

$$
\begin{aligned}
& \text { In } w_{n}={ }^{-}{ }_{s}+{ }^{-}{ }_{t}+{ }^{-} z+{ }^{-}{ }_{a}: a g e n_{n}+{ }^{-}{ }_{w}: w_{h i t e}+{ }^{\circ}: d_{n}^{f} \\
& +{ }^{f}:\left( \pm_{s ; t} \text { i } \quad 0: 5\right): d_{n}^{f}+,{ }^{m}:\left( \pm_{s ; t} \text { i } \quad 0: 5\right):\left(1 ; \quad d_{n}^{f}\right)+{ }^{2} n
\end{aligned}
$$

where $\mathrm{n}$ is the subscript for individual, age indicates the age of the individual, white is an indicator for race and ${ }^{-}$z represents vectors of ..xed exects for industry, occupation and grade. Table 2 gives estimation results for the sample of 62,753 observations. The ..rst column shows the estimation results for a model similar to the one used in the previous subsection where we ignore personal characteristics. The estimated gender wage gap of $20.8 \%$ is almost the same as the one presented in the ..rst column of Table 1. The second column shows the parameter estimates of equation (27) where we include race and age and ..xed exects for grade, industry and occupation. Now, the gender wage gap reduces to $15.8 \%$. So $5 \%$-points of the gender wage gap can be attributed to dixerences between males and females in terms of education, industry and occupation. 
The third column shows that the classical gender wage gap (i.e., that attributable to nonhousehold exects) reduces further to $12.4 \%$ if we introduce the household interaction exect. This exect is smaller than in the estimates using the aggregate data, but it is still signi..cantly dixerent from zero.

The fourth column shows the estimation results if we impose, $f=i, m=7$ : A gain, as indicated by the value of the F-statistic we cannot reject the hypothesis that both household interaction exects have the same size (in absolute terms).

\subsection{Sensitivity analysis}

To investigate the robustness of our results we performed several types of sensitivity analyses. ${ }^{15}$ In the ..rst sensitivity analysis, we investigated to what extent our results are infuenced by our assumption that all state speci..c dixerences and trend changes in the gender wage gap are due to the household interaction exect. We did this previously when using the aggregate data and now we investigate to what extent the household interaction exect is also robust when using micro data.

We start with the introduction of a trend change in the gender wage gaps and then introduce state speci..c wage gaps. The ..rst column of Table 3 shows that without including the household interaction exect there is a trend-like decline in the gender wage gap of $0.47 \%$-points per year. The second column of Table 3 shows the trend in the wage gap when the household interaction exect is included. Now the gender wage gap decreases each year on average by $0.41 \%$-points. The coec cient representing the household interaction exect with a value of -0.11 is smaller than before (in absolute terms), but still dixers signi..cantly from zero.

The third column of Table 3 shows the results if, in addition to a trend change in the gender wage gap, we introduce state-speci..c gender wage gaps. This means that the information on which the household interaction exect has to be estimated is even more limited. Fixed statespeci..c gender wage gaps are now assumed not to be related to ..xed state-speci..c dixerences in \pm nor are they assumed to be related to trend changes in \pm over time. As shown even now we ..nd a household interaction exect of -0.069 that is dixerent from zero at conventional levels of signi..cance.

This part of the sensitivity analysis also gives an indication of the importance of the household interaction exect in the explanation of the gender wage gap. In the employment shares of males

\footnotetext{
${ }^{15}$ One of the sensitivity analysis not reported in Tables 3 and 4 is the investigation whether the results are sensitive to the number of working hours per week. In our baseline analysis our sample consists of people that work full-time having a working week between 35 and 50 hours. If we restrict our sample to people that work exactly 40 hours per week our sample reduces to 45,421 observations. T his restriction of the sample hardly axects the estimated household interaction coec cient, which then has a value of -0.177 (t-value: 5.3 ). A nother sensitivity analysis not reported in tables is where we restricted the sample to whites. Then we ..nd a household interaction coec cient of -0.159 (t-value: 5.0 ).
} 
there is time invariant cross-state variation and there is a trend-like decline across the states. As shown in the theoretical part of the paper the employment share of males axects the gender wage gap. There is also time invariant cross-state variation in the gender wage gap and there is a trend-like decline across the states. In terms of relationships between the two we distinguish two extreme cases. The .rst extreme is where all time invariant cross-state variation in the employment shares of males is related to the time invariant cross-state variation in the gender wage gap. The same holds for the trend-like decline across the states. In this case in our empirical speci..cation we do not allow for independent time invariant cross-state wage gaps or independent cross-state trend-like changes. All of these exects are assumed to captured by the coet cient , ; the household interaction exect. In this case we measure the maximum household interaction exect. This maximum estimate is presented in the third column of Table 2. So, the remaining classical wage gap is $12.4 \%$, while it was $15.8 \%$ in the second column of Table 2 . The household interaction exect reduced the gender wage gap by about $22 \%$.

At the other extreme however, it could be that none of the time invariant cross state variation in the gender wage gap is related to the time invariant cross-state variation in the employment share of males. The same could hold for the trend-like decline across states. In this case we introduce time invariant cross state ..xed exects for the wage gaps and also allow for a trendlike change in the wage gaps. Now, measures the minimum household interaction exect since all of ..xed state dixerences and the trend-like decline are assumed to be unrelated to household interaction. This minimum estimate is presented in column (3) of Table 3. Whereas the value, of -0.163 in column ( 3 ) of Table 2 can be considered as an upper bound of the household interaction exect, the value of -0.069 in column (3) of Table 3 can be considered as the lower bound. The lower bound value implies that about $9 \%$ of the average gender wage gap is related to the household interaction exects. Combining both extremes we may conclude that the household interaction exect explains $10-20 \%$ of the overall gender wage gap. In the same way we can calculate the contribution of the household interaction exect to the decline in the gender wage gap. In column (1) of Table 3 the trend decline in the wage gap is $0.47 \%$ per year, in column (2) where the household interaction exect is included the trend decline in the wage gap reduces to $0.41 \%$ per year. So, the household interaction exect is responsible for about $13 \%$ of the decline in the gender wage gap. Additional estimates show that the dixerences in trend-like decline are hardly axected by introducing state speci..c gender wage gaps.

In our second sensitivity analysis we apply our estimation procedure to workers of age 35-44 and workers of age 45-54 years. Our theoretical model only predicts a household interaction based wage gap for young individuals. This is because older individuals have their career commitment inferred by their past performance and have their wages correspondingly bid up. The distinction between young and old in the model is dramatic, arising to the one period assumption on information about shirking. In reality, information would ‡ow out more smoothly, and thus gender 
dixerentials should decline more gradually. Nonetheless we should still expect to see some decline in the exect of \pm with age. Figures $2 \mathrm{a}$ and $2 \mathrm{~b}$ show that a broadly similar pattern of decline in average wage gap and decrease in male over-representation occurred in the older age groups as well. Column (4) of Table 3 shows the estimation results for the age group 35-44. The household interaction exect is smaller (in absolute terms) than for the younger age group and in fact it is not signi..cantly dixerent from zero. As indicated in footnote c of Table 3 after state-speci..c exects are included the household interaction exect is closer to zero. A pparently the household interaction exect does not seem to be relevant for this age group. The dixerence in earnings between whites and non-whites of the age group 35-44 is similar to the dixerence for the younger age group, the exect of age is substantially smaller. For this age group every year of becoming older increases the wage with $0.5 \%$.

As shown in the ..fth column of Table 3, for the age group 45-54 the household interaction coed cient is also smaller (in absolute terms) than the coet cients of the younger age group, although it is still signi..cantly dixerent from zero. However, as soon as state-speci..c wage gaps are included the household interaction vanishes. For the older workers there is a white non-white wage gap of $6.3 \%$, while age does not seem to matter. From all this we conclude that the data seems to support the existence of a household interaction exect only for younger workers. The increase in average wage gap by age, depicted in F igure 2b, is explained by the classical wage gap together with dixerences in characteristics, and not household interaction, as is consistent with the theoretical model.

Finally, we investigate to what extent our results are driven by labor supply exects ${ }^{16}$. It could be that the causality does not run from share of males to gender wage gap, but from gender wage gap to share of males. Then, the declining gender wage gap is causing an increased labor supply of females instead of the other way around. To test the validity of the labor supply exects we calculated the share of males in employment in three occupational groups by state and year. Our theoretical model predicts no relationship between occupational wage gaps and occupational male over-representation provided individuals are not more likely to marry someone of the same occupation. B ecause the occupational classi..cation changed from 1983 on we restrict our estimates to the period 1983-1998. The three groups we distinguish are (DOCC 1983-1997 codes):

Group 1 (1-12): A dministrators and oф cials (public administration), other executive administrators and managers, management related occupations, engineers, mathematical and computer scientists, natural scientist, health diagnosing occupations, health assessment and treating occu-

\footnotetext{
${ }^{16}$ T his part of our analysis is related to studies on occupational feminization of wages (see Sorensen (1990) and A Itonji and Blank (1999) for an overview). In these studies of cross-sectional data the fraction of women within occupations turns out to be negatively related to both male and female earnings. Note that in our sensitivity analysis the cross-sectional variation in the share of women within an occupation is picked up by the occupational ..xed exects.
} 
pations, teachers, lawyers and judges, other professional speciality occupations.

Group 2 (13-26): Health technologists and technicians, engineering and science technicians, other technicians, supervisors and proprietors (sales occupations), sales representatives, sales workers and sales related occupations, supervisors-administrative support, computer equipment operators, secretaries, stenographers and typists, ..nancial records and processing occupations, mail and message distributing, other administrative support occupations.

Group 3 (27-46): Private household service occupations, protective service occupations, food service occupations, health service occupations, cleaning and building service occupations, personal service occupations, mechanics and repairers, construction trades, other precisions production occupations, machine operators and tenders, fabricators, assemblers and inspectors, motor vehicle operators, other transportation occupations and material moving, construction laborers, freight, stock, material and other handlers, equipment cleaners and laborers, farm operations and managers, farm workers and related occupations, forestry and ..shing occupations, armed forces currently civilian.

Figures $3 a$ and $3 b$ depict the share of males in employment and relative wage of males respectively, for these occupational groupings. The relationship we estimate separately for each occupational group k is:

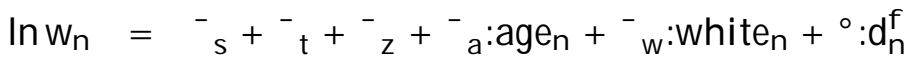

$$
\begin{aligned}
& +{ }_{,}^{-}: t_{s ; t}^{\infty}+\gg: t_{s ; t}^{0}+{ }^{2} n
\end{aligned}
$$

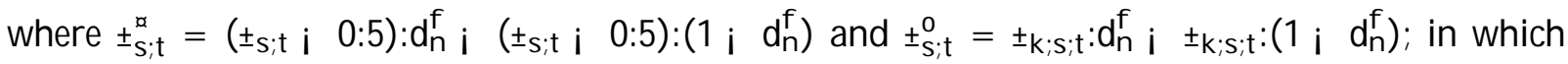
${ }_{k ; s ; t}$ is the normalized share of males at the level of occupational group $k$ in state $s$ at year $t{ }^{17}$ The new coec cient » indicates the exect of occupation speci..c shares of male employment. If this coec cient is signi..cantly negative and the household interaction coet cient , is no longer signi..cantly dixerent from zero, this indicates reversed causality. The reason is clear. If changes in the gender wage gap at the level of an occupational group are related to occupational group speci..c changes in the share of males, rather than to state level changes, it is probably a labor supply exect that is driving this relation.

The estimation results are shown in Table 4. The ..rst column of Table 4 shows that for the ..rst occupational group the new coec cient » does not dixer signi..cantly from zero, while the 'old' coec cient - does. From the results in the lower part of the ..rst column, where we omitted the occupational variable it appears that the classical gender wage gap in the ..rst occupational group is $6.3 \%$, which is substantially smaller than the average gender wage gap. Furthermore, the white non-white wage gap is 3.9\%-points, which is also smaller than average. The exect of

\footnotetext{
${ }^{17} \#_{k ; s ; t}$ is de..ned similarly to (18) as the share of male workers in occupational group $k$ in state $s$ and year $t$, divided by the share of males in the population in state $s$ and year $t$.
} 
age is quite substantial. Every year of growing older increases the wage by $2.8 \%$. The size of the coet cient of the household interaction exects is comparable to the one in the aggregate estimates.

The second column of Table 4 shows the estimation results for the second occupational group. Now the coec cient » is signi..cantly dixerent from zero, but with the wrong sign. If we omit the occupational variable the household interaction exects is dixerent from zero, but only at a 10\%-level of signi..cance. The white-non white wage dixerential and the exect of age for this occupational group are similar to the aggregate exects.

The third column of Table 4 gives the estimation results for the third occupational group. Here the coec cient » is not signi..cantly dixerent from zero. The household interaction exect dixers signi..cantly from zero. For this group of occupations we ..nd that the whitenon white wage dixerential is quite substantial $(9.9 \%)$, while the age exect is comparable to the average age exect.

All in all, we conclude from the estimation results presented in Table 4 that labor supply exects are not very important, while the household interaction exects is also valid for separate occupational groups.

\section{Conclusions}

The paper has developed a theoretical explanation of the gender wage gap which turns on the interaction between men and women in households. If men are over-represented in full-time employment, we show that ..rms rationally choose to hire women about whose labor market commitment they are unsure, only at strictly lower wages than the men. Further, the wage gap favoring men is positively related to the degree of male over-representation in the relevant labor market, thus allowing empirical testing of the model and distinguishing it from previous theories of discrimination. We tested our theory using CPS data over the period 1979-98 and found reasonably strong supporting evidence. We took an upper bound for the household interaction exect to be the estimate obtained when all trend like changes and state-speci..c dixerences in the gender wage gap were assumed to be captured by it. We estimated a lower bound for the household interaction exect under the assumption that neither trend like changes nor state-speci..c dixerences were related to it. The exect was signi..cant even at the lower bound, and was robust to sensitivity analysis. Taking these lower and upper bounds, we conclude that between 10 and $20 \%$ of the average gender wage gap, and the decline in the gender wage gap, over the period 1979-1998 is related to the household interaction exect.

\section{R eferences}

[1] A nderson, S. and P. Francois (1997) Unequal Access and the Detrimental Impact of Development on Women, mimeo, Queen's University, K ingston, Ontario. 
[2] A Itonji, J.G. and R.M. Blank (1999) Race and Gender in the Labor Market, in: O. A shenfelter and D. Card (eds.), Handbook of Labor E conomics, volume 3, 3143-3259.

[3] Beaudry, P. (1994) Entry Wages Signalling the Credibility of Future Wages: A Reinterpretation of the Turnover-E $\$$ ciency-Wage Model, Canadian J ournal of Economics; 27(4), 884-902.

[4] Becker, G. S. (1957) The economics of discrimination, Chicago: University of Chicago Press.

[5] Blau, F. and M. Ferber (1986) The economics of women, men and work, Englewood Clias, N.J .:Prentice-Hall.

[6] Bowlus, A.J . (1997) A search interpretation of male-female wage dixerentials, J ournal of Labor E conomics, 15, 4, 625-57.

[7] Bulow, J.I. and L. Summers (1986) A theory of dual labor markets with application to industrial policy, discrimination and K eynesian unemployment. J ournal of Labor E conomics, $4,3$.

[8] Cain G.G. (1986) The economic analysis of labor market discrimination: a survey. In 0 . A shenfelter and R. Layard, eds. Handbook of Labor E conomics, N orth Holland, A msterdam.

[9] Darity, W. A. and P. L. M ason (1998) Evidence on discrimination in employment: codes of color, codes of gender, J ournal of E conomic Perspectives, Summer, 63-90.

[10] Engineer, M . and L. Welling (1997) Human capital, true love, and gender roles: is sex destiny? mimeo, Department of Economics, University of Victoria, B ritish Columbia, forthcoming J ournal of E conomic Behavior and Organization.

[11] Feenberg, D. (1999) CPS Labor Extracts 1979-1998, NBER, J anuary 1999.

[12] Francois, P. (1998b) A theory of gender discrimination based on the household, J ournal of Public E conomics, 68 (1) 1-32.

[13] Francois, P. (1998a) Self-ful..lling Gender Stereotypes: A Theory of the Within Occupation Gender Gap, mimeo, Tilburg University, Tilburg, The Netherlands.

[14] Gunderson, M. (1989) Male-Female wage dixerentials and policy responses, J ournal of E conomic Literature, XXVII, M arch, 46-72.

[15] K awaguchi, A . (1997) A feedback model of gender discrimination, mimeo, Faculty of Economics, Otemon Gakuin University, Osaka, J apan.

[16] Milgrom, P. and S. Oster (1987) J ob discrimination, market forces and the invisibility hypothesis, Q uarterly J ournal of E conomics, A ugust, CII, 453-76.

[17] O'N eill, J . and S. Polachek (1993) W hy the gender wage gap narrowed in the 1980s. J ournal of Labor E conomics, 11, 1, 205-228.

[18] Osterman, P. (1982) A \& rmative action and opportunity: a study of female quit rates, Review of Economics and Statistics, 64, 4, 604-12.

[19] Popenoe, J . (1993) American family decline, 1960-1990: a review and appraisal, J ournal of Marriage and the Family, 55, 527-555.

[20] Phelps, E.S. (1973) The statistical theory of racism and sexism, American E conomic Review, $62,659-61$.

[21] Reskin, B.F. and P.A. Roos (editors) (1991) J ob queues and gender queues: explaining women's inroads into male occupations, P hiladel phia, Temple University Press. 
[22] Shapiro, C. and J. Stiglitz (1984) Equilibrium unemployment as a worker-discipline device, A merican Economic Review, 74, 433-444.

[23] Sorensen, E. (1990) The crowding hypothesis and comparable worth, J ournal of Human Resources, 25, 55-89.

[24] V iscusi, W. K. (1980) Sex dixerences in worker quitting, J ournal of Human Resources, 15, Summer, 388-98. 


\section{A ppendix 1: Proof of Proposition 2}

We derive a sulc cient condition under which an eф ciency wage equilibrium satisfying the characteristics stated above exists. In such an equilibrium it is pro..t maximizing for ..rms to follow strategies ensuring that workers who contribute e in employment are re-hired, and workers who shirk are dismissed. We also show that young workers receive equilibrium wages that dixer by gender, denoted $w_{\alpha}^{m} ; w_{\infty}^{f}$ and that the old receive equilibrium wages that are gender invariant, denoted $w_{x}^{\text {old: }}$

First note that by competition between ..rms, if an equilibrium exists in which young and old of both sexes are hired it is necessary that:

$$
E^{m}\left(w_{\triangleright}^{m}\right)=E^{f} w_{\propto \alpha}^{f}=E^{\text {old }}{ }^{3} w_{\infty}^{\text {old }}
$$

If not, some..rms would be making higher expected pro..ts and would bid away other's employees upsetting the equilibrium. Thus, equilibrium relative wages $w_{\alpha}^{\text {old }} ; w_{\alpha}^{m}$ and $w_{\infty}^{f}$ are necessarily related uniquely by these conditions, for given \pm We construct an equilibrium in which men are over-represented in good jobs, i.e. $\pm>\frac{1}{2}$ : Recall that the wages paid to young employees do not axect their incentive compatibility conditions, since these depend only on future wages, wold: This can be seen directly from (3) and (5) where the w terms cancel out of these equations. Thus, ignoring the incentive compatibility conditions for now, we focus on wages necessary to induce participation. For a young female worker the participation constraint is:

$$
w^{f} \text { i } c(e) \text { i } k+\frac{p^{3}}{1 i p} w^{\text {old }} i c(e), 0:
$$

Let the wage solving (24) with equality be denoted $w_{p c}^{f}{ }^{i} w^{\text {old }}{ }^{\Phi}$ : By re-arrangement it is given by:

$$
w_{p c}^{f}{ }^{3} w^{\text {old }}=c(e)+k i \frac{p^{3}}{1 ; p} w^{\text {old }} i c(e){ }^{\prime}:
$$

It is a decreasing function of $w^{\text {old }}$ because the higher the wage when old, the lower is the current wage a worker will require to participate when young, in antjcipation of higher future wages.

We now demonstrate that with $\pm>\frac{1}{2} ; w_{c}^{f}=w_{p c}^{f} w^{\text {old }^{q}}$ : If $\pm>\frac{1}{2}$; to satisfy (23); young men must receive a higher wage than young women, point (i). This has already been solyed for in condition (14) and we denote the pairs of wages satisfying this condition by $\left\{\mathrm{w}^{\mathrm{m}}{ }^{1} \mathrm{w}^{\mathrm{f}} ; \mathrm{w}^{\mathrm{f}} \mathrm{g}\right.$ : Necessarily any equilibrium wages must be from this set of pairs, since otherwise ..rm indixerence conditions would be violated. C3onsider two candidate equilibrium wages satisfying (14) denoted $w_{1}^{f}$, and correspondingly $w^{m} w_{1}^{f} \quad$ : Suppose that $w_{1}^{f} \geqslant w_{p c}^{f} i w^{\text {old }}{ }^{f}$ : Then, necessarily $w^{m} w_{1}^{f}>w_{p c}^{f}{ }^{i} w^{\text {old }^{\phi}}$ too. Thus at the pair $w^{m} w_{1}^{f} ; w_{1}^{f}$ both sex's participation constraints are satis..ed but, from (1) either some young quali..ed men are not able to obtain good jobs, or some young quali..ed women are not.' But, then ...rms can raise pro..ts by hiring these individuals at wages below $w_{1}^{f}$ and $w^{m} \quad w_{1}^{f} \quad$ respectively, because those who were both quali..ed and unemployed would be willing to participate at. those wages, so that these wages cannot constitute an equilibrium. Thus, necessarily, $w_{s}^{f}: w_{p c}^{f} i w^{\text {old }}{ }^{q} ;$ and since it can never be strictly less, we have $w_{c}^{f}=w_{p c}^{f} i w^{\text {old }}{ }^{f} ;$ for any equilibrium value of $w_{c}^{\text {old }}$ : So that:

$$
w_{\alpha}^{f}=c(e)+k i \frac{p^{3}}{1 i p} w_{\triangleright d}^{\text {old }} i c(\bar{e}) \text { : }
$$


Thus, necessarily, male equilibrium wages are $w_{x}^{m}={ }^{3} w^{m}{ }^{3} w_{p c}^{f}{ }^{i} w_{p d}^{o l d} \phi^{\prime \prime}$; so that:

$$
w_{\propto}^{m}=c(e)+k i \frac{p^{3}}{1 i p} w_{\propto}^{\text {old }} i c(e)+N y^{\mu} \pm_{i} \frac{1}{2}^{\text {व }}:
$$

Note that, at these wages, since (24) binds, young women are indixerent to participating, and all young men strictly prefer to participate. Thus male wages would fall, upsetting the equilibrium, unless all young men were oxered good jobs, so that point (iii) in the proposition must be true. Thus we immediately have that $\pm=\frac{\mathrm{q}}{2 \mathrm{~N}}>\frac{1}{2}$; and the young males' probability of obtaining a good job is 1 . Correspondingly women have probability of obtaining a good job given by $\frac{N_{i} q}{q}$ or $\frac{\left(1_{i} \pm N\right.}{q}$ : Finally, we solve explicitly the value of $w_{3}^{f}$ and $w_{x}^{\text {old }}$ by using $E^{\text {old }}{ }^{i} w^{\text {old }^{\phi}}{ }^{\phi}=E^{f} w_{x}^{f}$ and condition (26): The condition $E^{\text {old }}{ }^{i} w_{\infty}^{o l d}{ }^{\Phi}=E^{f} \quad w_{s}^{f}$ yields:

$$
\mathrm{w}_{\mathrm{x}}^{\mathrm{f}}=\mathrm{w}_{\mathrm{x}}^{\mathrm{old}} \mathrm{i} \quad \frac{\mathbb{N}}{2} \mathrm{y} ;
$$

which, when combined with (26) and (14) yields unique solutions for these wages:

$$
\begin{aligned}
w_{\infty}^{\text {old }} & =c(e)+(1 ; \quad p) k+(1 ; \quad p) \pm \frac{N y}{2} \\
w_{\infty}^{f} & =c(e)+(1 ; \quad p) k i p \pm \frac{N y}{2} \\
w_{a}^{m} & =c(e)+(1 ; \quad p) k+(2 \pm i \quad p \pm i \quad 1) \frac{N y}{2} ;
\end{aligned}
$$

corresponding to those stated in the proposition. These three wages are necessary both for ...rm indixerence to hold, and for participation constraints to be satis..ed for both sexes. These wages are also the unique values satisfying these conditions since it is necessary that the participation constraint for females binds when there are some women who do not obtain full-time work. Finally, for these wages to constitute an equilibrium it is necessary that incentive compatibility, condition (5); holds, but it will not have to bind, since all men have the opportunity to obtain full-time work. A necessary and suc cient condition for this to hold is that $\mathrm{w}_{x}^{\text {old }}$ is high enough. Substituting in for $w_{\alpha}^{\text {old }}$ into (5) yields the following restriction on the primitives:

$$
y, \frac{2 c(\bar{e})}{p+\mathbb{N}}:
$$

So that a necessary and suc cient condition for equations (15); (16); and (17) to constitute an equilibrium is that (28) holds. $¥$

\section{A ppendix 2: Details of the data}

We use data from ...les from1979 to 1998 of the Current Population Survey (CPS) as prepared by the NBER and made available through a CD-ROM. As indicated in the main text. As indicated in the main text we only use March data from every year. Our main analysis is based on data for individuals age 25-34 years. In addition to that we did analyses on data for individuals age 45-54 years. This appendix describes the way we constructed the datasets we used in the analysis and it gives some descriptives of these datasets. Our main task was to ...nd variables that were de..ned in a consistent way throughout the period 1979-98. See for details on the NBER-dataset Feenberg (1999). 


\subsection{Variables}

We create own variables and use the variable names as de..ned in the NBER-appendices, referring to them in italics. Note that \pm is de..ned in the main text.

1. Wage: hourly wage = earnwke/ uhourse. Here, earnwke = edited or computed earnings per week in the job. Includes overtime tips and commissions. This information is partly based on the question "How much does ... usually earn per week at this job before deductions? Include any overtime pay, commissions, or tips usually received. Dollars." Uhourse is de..ned as the number of hours per week the individual usually works.

2. Sex: Code 1-2, recoded to $0-1,1$ being females.

3. State: 51.1960 Census Codes for state.

4. Year: 20 interview year (last two digits): 79-98.

5. Age: Years of age, from 1994 on, this is derived from a question about date of birth.

6. White: Derived from the variable race. For the period 1979-88 this variable had three codes ( $1=$ W hite, $2=$ Black, $3=0$ ther), for the period 1989-95 it had four codes ( $1=$ White, $2=$ Black, 3=A merican Indian, 4=0 ther), from 1996 on it had ..ve codes ( $1=$ W hite, $2=B$ lack, 3=A merican Indian, 4=A sian or Paci..c Islander, 5=0ther).

7. Grade: Until 1991 we use the variable gradeat that is de. ned as the highest grade of school attended. From 1992 on we use the variable grade92, the highest grade attended. In 1992 the BLS switched from years of schooling measure to a credential oriented measure. The coding of gradeat goes from 0 to 18, the coding of grade92 goes from 31 to 46. Feenberg (1999) indicates that "rumor has it that a labor economist who estimated wage equations for 1991 and 1992 without noticing the dixerence in the CPS education measure was surprised only by the change in the constant term." We used dummy variables for each educational category until 1991 and each educational category from 1992 on.

8. Occupation: For the period 1979-82 we use the variable docc70, the 2-digit Detailed Occupation Recode from the 1970 Census, and for the period from 1983 on we use docc80, the 2-digit Detail Occupation Recode from the 1980 Census. This means that we distinguish 40 occupational categories before 1983 and 44 categories from 1983 on.

9. Industry: This is the variable dind, an NBER created 2-digit Detailed Industry Classi..cation Code that is consistent over all the years covered.

\subsection{From gross sample to net sample (age group 25-34 years)}

If we only restrict the data to individuals age 25-34 in the $M$ arch surveys the total sample for the 51 states and 20 years counts 118,403 observations. This is what we call our gross sample. In this gross sample for some variables not all 118,403 observations are valid or available: earnwke $(82,255$ observations), uhourse (82,560 observations), occupation (109,380 observations), industry (107,029 observations).

To create our net sample we select only those observations satisfying all of the following four criteria:

1. Employed (but not self-employed); $\operatorname{class}^{2}(1 ; 4)$ and class94 ${ }^{2}(1 ; 5)$ :

2. Full-time; ftpt79=1, ftpt89 $=2$ and ftpt94 $=2$.

3. Strictly positive usual weekly earnings; earnwke $>0$.

4. B etween the 35 and 50 usual weekly working hours; uhourse ${ }^{2}(35 ; 50)$.

As stated in the main text this gives a net sample which 62,753 observations. In the table below are the number of observations of the gross sample which satisfy each of the criteria described above.

Criteria

1. Employed

2. Full-time

3. Positive earnings

4. Between 35 and 50 hours
\# satisfying

97,287

75,440

82067

66,280 percentage (\%)

82.2

63.7

69.3

56.0 
A fter applying these criteria a net sample of 62,753 observations remains. We handled the datasets for the age groups 35-44 and 45-54 years in the same way.

\subsection{Descriptives}

Table A 1 gives descriptives of datasets we use in the analysis.

Table A 1 Descriptives of various datasets; averages (standard deviations)

$\begin{array}{llllll}(1) & \text { (2) } & \text { (3) } & \text { (4) } & \text { (5) } & \text { (6) }\end{array}$

$\begin{array}{lllllll}\text { w } & 9.88(5.30) & 11.92(6.85) & 12.24(7.30) & 13.48(6.37) & 10.01(5.02) & 9.26(4.53)\end{array}$

$\begin{array}{lllllll}\text { f emale } & 0.44 & 0.44 & 0.43 & 0.52 & 0.63 & 0.25\end{array}$

$\begin{array}{lllllll}\text { age } & 29.5 & 39.3 & 49.2 & 29.7 & 29.4 & 29.5\end{array}$

$\begin{array}{lrrrrrr}\text { white } & 0.86 & 0.85 & 0.87 & 0.89 & 0.85 & 0.84\end{array}$

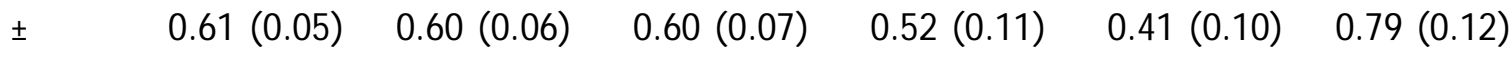

$\begin{array}{ccccccc}\text { A ge group } & 25-34 & 35-44 & 45-54 & 25-34 & 25-34 & 25-34 \\ \text { Years } & 1979-98 & 1979-98 & 1979-98 & 1983-98 & 1983-98 & 1983-98 \\ \text { Occupations } & \text { all } & \text { all } & \text { all } & \text { group 1 } & \text { group 2 } & \text { group 3 } \\ \text { Observations } & 62,753 & 53,224 & 37,275 & 13,148 & 15,858 & 19,780\end{array}$




\section{$7 \quad$ Tables and graphs}

Table 1 Estimation results log-wage regressions using aggregate dataa)

(1)

$\begin{array}{ccc}\circ & -0.214(49.8) & -0.147(15.0) \\ \mathrm{f} & - & -0.356(5.1) \\ { }_{\mathrm{m}} & - & 0.287(4.5) \\ - & - & -\end{array}$

trend $a d^{f}$

state a d

$\overline{\mathrm{R}}^{2}$

0.871

0.874
(2)

$(3)^{b)}$

$-0.148(15.1)$
$-0.319(7.6)$
$-$
no
0.874

no

(4)

(5)

(6)

$-0.304(39.0) \quad-0.261(19.3)$

$-$
$0.0102(13.5)$
no
0.882

$-0.168(3.9)$

$-0.101(2.2)$

$0.0092(11.8) \quad 0.0094(12.1)$

no

yes

a) Weighted least squares regressions. "trend" is a time trend that has a value of 0 in 1979 (19 in 1998),

0.883

0.888 therefore ${ }^{\circ}$ represents the value of the wage gap in 1979. Fixed exects for states and years are included, 2,040 observations; t-values in parenthesis, $\overline{\mathrm{R}}^{2}$ corrected for degrees of freedom.

b) The F-statistic for the test ${ }^{\mathrm{f}}=\mathrm{i}, \mathrm{m}=$, equals 0.44 . 
Table 2 Estimation results baseline model ${ }^{a)}$

$\begin{array}{ccccc} & (1) & (2) & (3) & \left.(4)^{\mathrm{b}}\right) \\ \circ & -0.208(58.7) & -0.158(44.3) & -0.124(17.7) & -0.124(17.7) \\ \mathrm{f} & - & - & -0.174(3.7) & - \\ \mathrm{m} & - & - & 0.154(3.6) & - \\ \sim & - & - & - & -0.163(5.6) \\ \text { White } & - & 0.073(16.6) & 0.073(16.6) & 0.073(16.6) \\ \text { Age } & - & -0.019(38.2) & 0.019(38.1) & 0.019(38.1) \\ \overline{\mathrm{R}}^{2} & 0.227 & 0.490 & 0.490 & 0.490\end{array}$

a) Ordinary least squares, all estimates include dummy variables for calendar year (19) and state (50). Estimates (2)- (4) also include dummy variables for grade (19 before 1992, 16 from 1992 on), industry (47) and occupation (40 categories before 1983, 44 categories from 1983 on); t-values in parenthesis, $\bar{R}^{2}$ corrected for degrees of freedom, sample of 62,753 observations.

b) The F-statistic for the test ${ }^{\mathrm{f}}=\mathrm{i}, \mathrm{m}=$, equals 0.09 . 
Table 3 Sensitivity analysis I $^{\text {a) }}$

(1)

$\begin{array}{cc}\circ & -0.200(31.8) \\ - & - \\ \text { White } & 0.073(16.6) \\ \text { Age } & 0.019(38.1) \\ \text { Trend } a d_{f} & 0.0047(8.2) \\ \text { State } a d_{f} & \text { no } \\ \overline{\mathrm{R}}^{2} & 0.491\end{array}$

(2)

$\begin{array}{cc}-0.172(17.5) & - \\ -0.110(3.7) & -0.069(2.0) \\ 0.073(16.6) & 0.074(16.8) \\ 0.019(38.1) & 0.019(38.2) \\ 0.0041(7.0) & 0.0042(7.1) \\ \text { no } & \text { yes } \\ 0.491 & 0.491\end{array}$
$-0.291(27.9) \quad-0.326(26.2)$ $-0.045(1.5) \quad-0.085(2.8)$ $0.075(15.1) \quad 0.063(9.9)$ $0.005(9.1) \quad 0.001(0.8)$

$0.0071(10.6) \quad 0.0056(7.0)$ 25 ; 34 62,753

0.540

(4)

(5)

\begin{tabular}{cc}
35 & i 44 \\
53,224 & 45 i 54 \\
\hline & 37,275
\end{tabular}

\# of observations

a) Ordinary least squares. "Trend" is a time trend that has a value of 0 in 1979 (19 in 1998), therefore - represents the value of the wage gap in 1979. All estimates include dummy variables for calendar year (19), state (50), grade (19 before 1992, 16 since 1992), industry (47) and occupation (40 categories before 1983, 44 categories from 1983 on); t-values in parenthesis, $\overline{\mathrm{R}}^{2}$ corrected for degrees of freedom.

b) If state-speci..c wage gaps are included the coec cient of the trend in the wage gap is 0.0046 (7.9).

c) If state-speci..c wage gaps are included the value of the household interaction exect is $-0.031(0.9)$

d) If state-speci..c wage gaps are included the value of the household interaction exect is $-0.019(0.5)$. 
Table 4 Sensitivity analysis II - Separate estimates for occupational categories and occupational category speci..c share of males in employment ${ }^{a}$ )
(1)
(2)
(3)

$\begin{array}{cccc}\text { Occupations } & 1 \mathrm{i} 12 & 13 \mathrm{i} 26 & 27 \mathrm{i} 46 \\ \circ & -0.030(1.0) & -0.177(7.2) & -0.176(4.5) \\ - & -0.138(1.9) & -0.165(2.6) & -0.109(1.8) \\ \text { White } & 0.039(3.6) & 0.066(7.8) & 0.099(12.8) \\ \text { Age } & 0.028(25.1) & 0.019(19.6) & 0.017(17.9) \\ » & -0.039(1.2) & 0.075(2.4) & 0.001(0.0) \\ \overline{\mathrm{R}}^{2} & 0.391 & 0.375 & 0.405 \\ \text { without »b) } & & & \\ \circ & -0.063(4.4) & -0.126(9.5) & -0.170(17.9) \\ - & -0.177(2.7) & -0.105(1.8) & -0.108(1.9) \\ \text { \# of obs: } & 13,148 & 15,858 & 19,780\end{array}$

a) Ordinary least squares, period 1983-98, age group 25-34. All estimates include dummy variables for calendar year (19), state (50), grade (19 before 1992, 16 since 1992), industry (47) and occupation (11 in (1), 13 in (2), 19 in (3)); t-values in parenthesis, $\bar{R}^{2}$ corrected for degrees of freedom.

b) Since the estimation results of the other coed cients and the $\overline{\mathrm{R}}^{2}$ are virtually unaxected we only report the coet cients ${ }^{\circ}$ and ${ }^{-}$. 

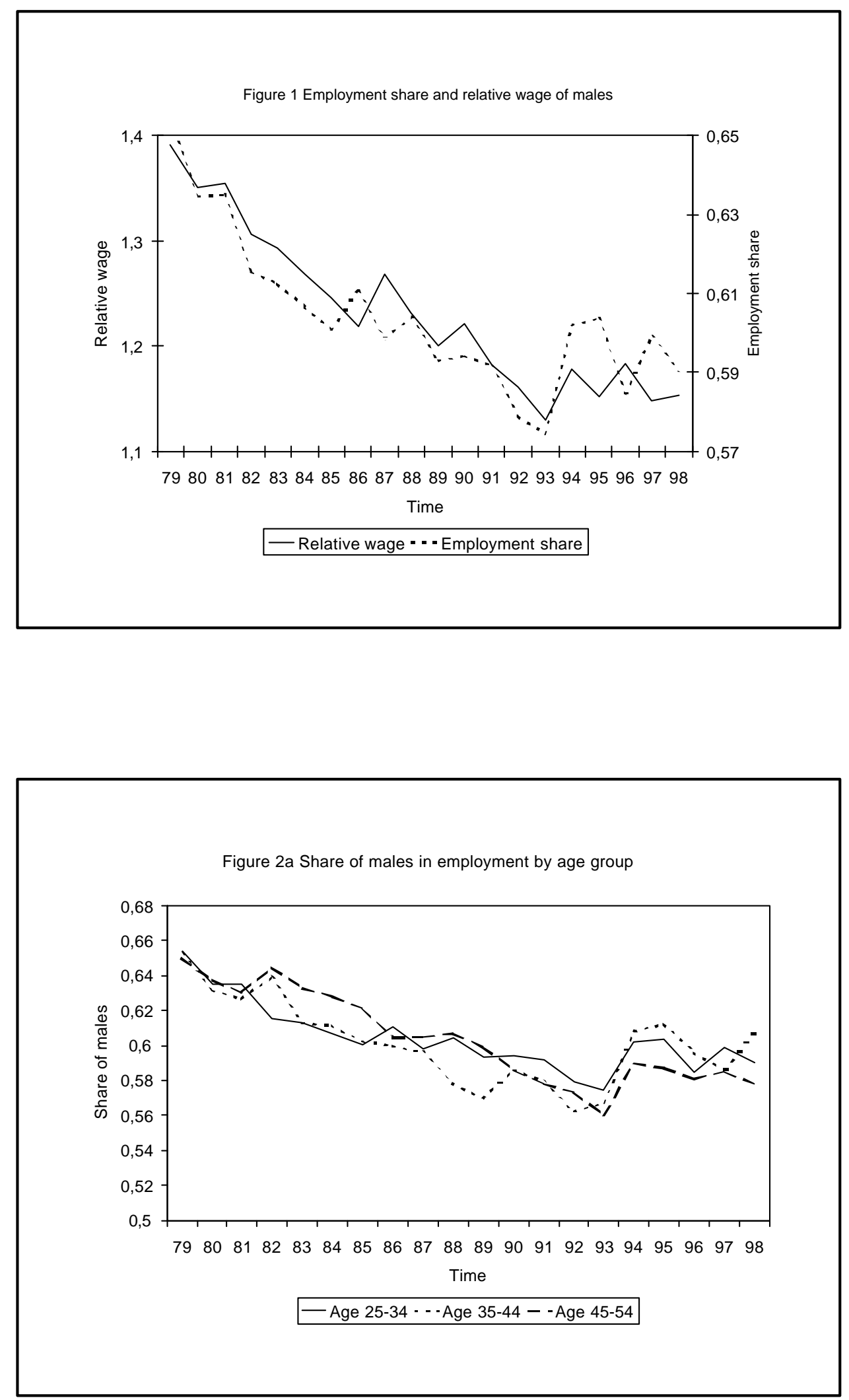
Figure $2 b$ Relative wage of males by age group

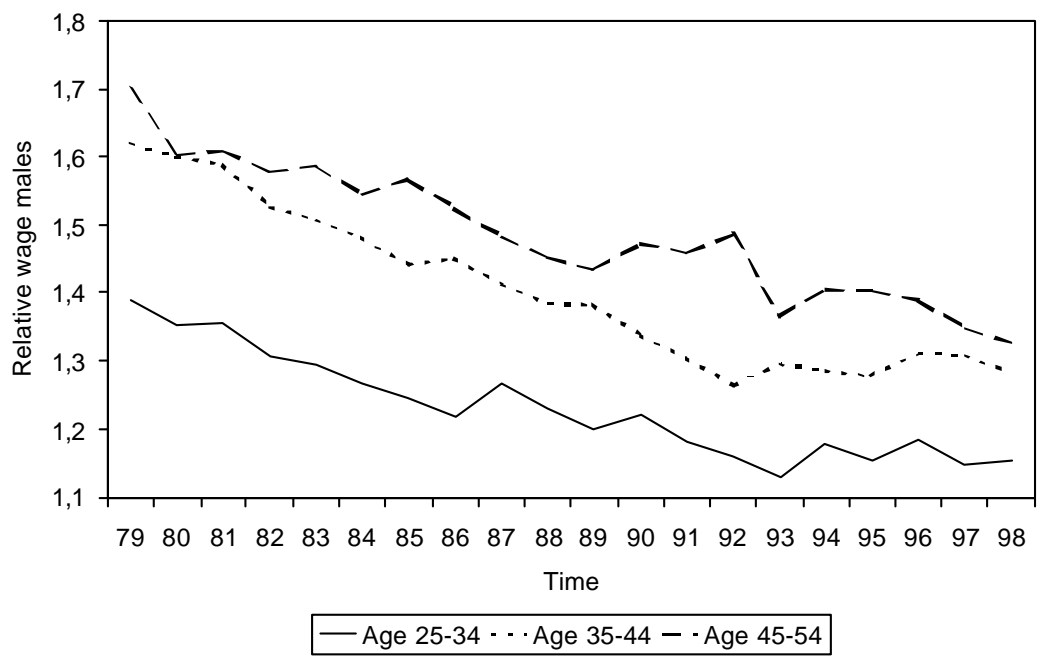

Figure 3a Share of males in employment by occupational group

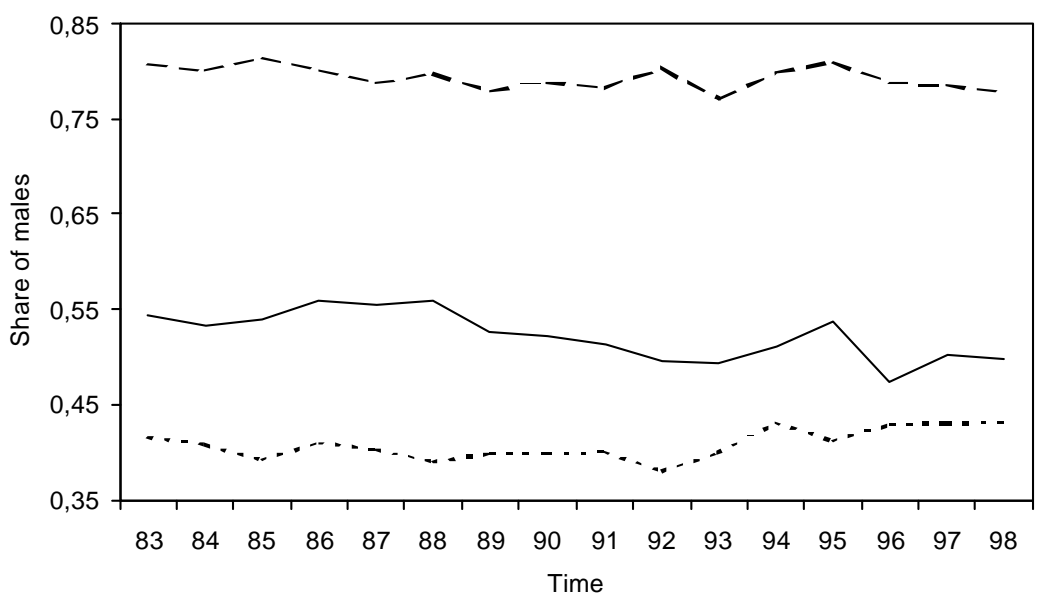

-Group 1 - - Group 2 - - Group 3 


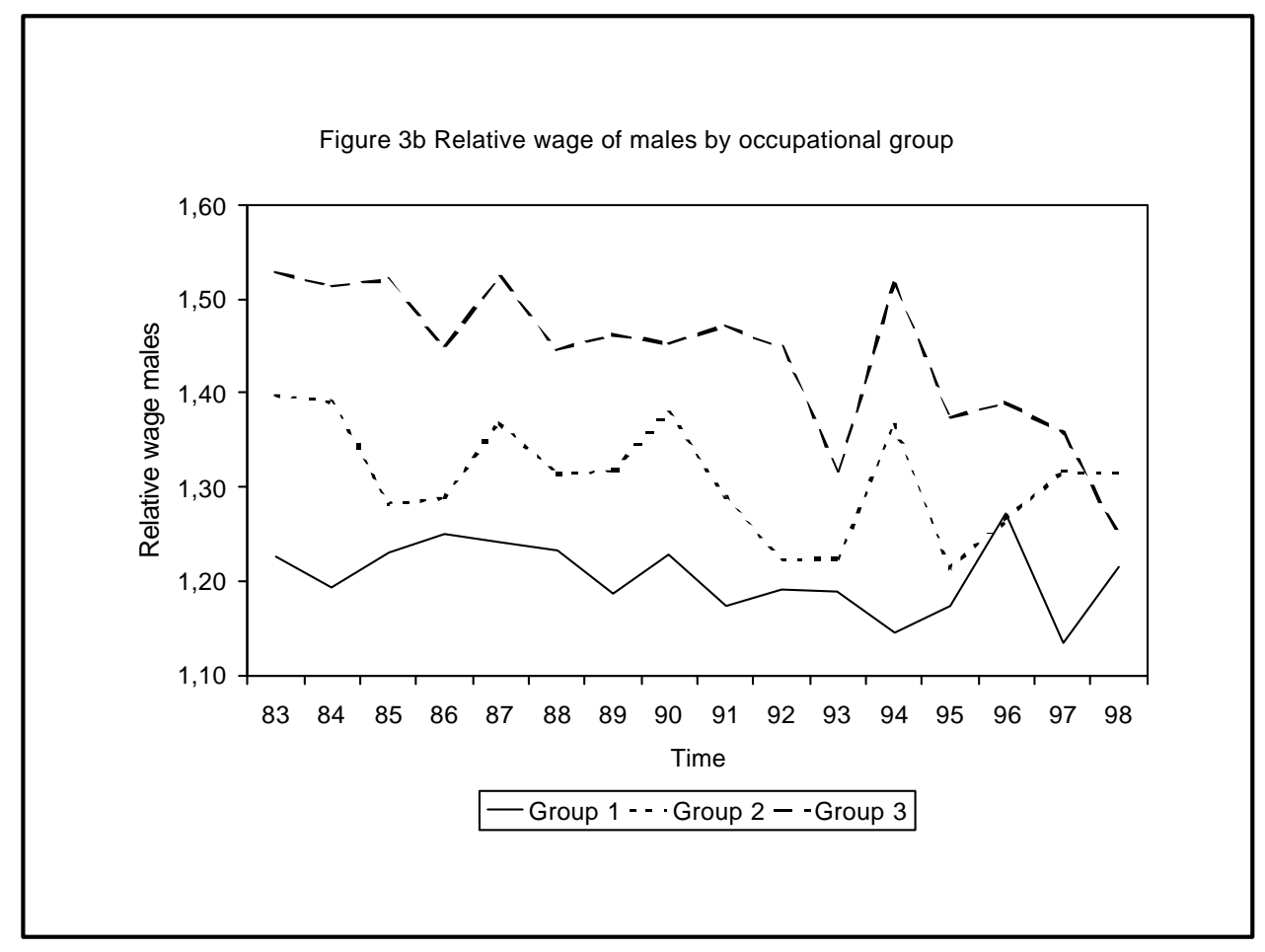




\section{IZA Discussion Papers}

\begin{tabular}{|c|c|c|c|c|}
\hline No. & Author(s) & Title & Area & Date \\
\hline 101 & $\begin{array}{l}\text { L. Husted } \\
\text { H. S. Nielsen } \\
\text { M. Rosholm } \\
\text { N. Smith }\end{array}$ & $\begin{array}{l}\text { Employment and Wage Assimilation of Male First } \\
\text { Generation Immigrants in Denmark }\end{array}$ & 3 & $1 / 00$ \\
\hline 102 & $\begin{array}{l}\text { B. van der Klaauw } \\
\text { J. C. van Ours }\end{array}$ & $\begin{array}{l}\text { Labor Supply and Matching Rates for Welfare } \\
\text { Recipients: An Analysis Using Neighborhood } \\
\text { Characteristics }\end{array}$ & $2 / 3$ & $1 / 00$ \\
\hline 103 & K. Brännäs & $\begin{array}{l}\text { Estimation in a Duration Model for Evaluating } \\
\text { Educational Programs }\end{array}$ & 6 & $1 / 00$ \\
\hline 104 & S. Kohns & $\begin{array}{l}\text { Different Skill Levels and Firing Costs in a } \\
\text { Matching Model with Uncertainty - } \\
\text { An Extension of Mortensen and Pissarides (1994) }\end{array}$ & 1 & $1 / 00$ \\
\hline 105 & $\begin{array}{l}\text { G. Brunello } \\
\text { C. Graziano } \\
\text { B. Parigi }\end{array}$ & $\begin{array}{l}\text { Ownership or Performance: What Determines } \\
\text { Board of Directors' Turnover in Italy? }\end{array}$ & 1 & $1 / 00$ \\
\hline 106 & $\begin{array}{l}\text { L. Bellmann } \\
\text { S. Bender } \\
\text { U. Hornsteiner }\end{array}$ & $\begin{array}{l}\text { Job Tenure of Two Cohorts of Young German Men } \\
1979 \text { - 1990: An analysis of the (West-)German } \\
\text { Employment Statistic Register Sample concerning } \\
\text { multivariate failure times and unobserved } \\
\text { heterogeneity }\end{array}$ & 1 & $1 / 00$ \\
\hline 107 & $\begin{array}{l}\text { J. C. van Ours } \\
\text { G. Ridder }\end{array}$ & $\begin{array}{l}\text { Fast Track or Failure: A Study of the Completion } \\
\text { Rates of Graduate Students in Economics }\end{array}$ & 5 & $1 / 00$ \\
\hline 108 & $\begin{array}{l}\text { J. Boone } \\
\text { J. C. van Ours }\end{array}$ & $\begin{array}{l}\text { Modeling Financial Incentives to Get Unemployed } \\
\text { Back to Work }\end{array}$ & $3 / 6$ & $1 / 00$ \\
\hline 109 & $\begin{array}{l}\text { G. J. van den Berg } \\
\text { B. van der Klaauw }\end{array}$ & $\begin{array}{l}\text { Combining Micro and Macro Unemployment } \\
\text { Duration Data }\end{array}$ & 3 & $1 / 00$ \\
\hline 110 & $\begin{array}{l}\text { D. DeVoretz } \\
\text { C. Werner }\end{array}$ & $\begin{array}{l}\text { A Theory of Social Forces and Immigrant Second } \\
\text { Language Acquisition }\end{array}$ & 1 & $2 / 00$ \\
\hline 111 & $\begin{array}{l}\text { V. Sorm } \\
\text { K. Terrell }\end{array}$ & $\begin{array}{l}\text { Sectoral Restructuring and Labor Mobility: } \\
\text { A Comparative Look at the Czech Republic }\end{array}$ & $1 / 4$ & $2 / 00$ \\
\hline 112 & $\begin{array}{l}\text { L. Bellmann } \\
\text { T. Schank }\end{array}$ & $\begin{array}{l}\text { Innovations, Wages and Demand for } \\
\text { Heterogeneous Labour: New Evidence from a } \\
\text { Matched Employer-Employee Data-Set }\end{array}$ & 5 & $2 / 00$ \\
\hline 113 & R. Euwals & $\begin{array}{l}\text { Do Mandatory Pensions Decrease Household } \\
\text { Savings? Evidence for the Netherlands }\end{array}$ & 3 & $2 / 00$ \\
\hline 114 & $\begin{array}{l}\text { G. Brunello } \\
\text { A. Medio }\end{array}$ & $\begin{array}{l}\text { An Explanation of International Differences in } \\
\text { Education and Workplace Training }\end{array}$ & 2 & $2 / 00$ \\
\hline 115 & $\begin{array}{l}\text { A. Cigno } \\
\text { F. C. Rosati }\end{array}$ & $\begin{array}{l}\text { Why do Indian Children Work, and is it Bad for } \\
\text { Them? }\end{array}$ & 3 & $2 / 00$ \\
\hline
\end{tabular}


117 S. Bender

A. Haas

C. Klose

118 M. A. Shields M. E. Ward

119 A. Lindbeck

D. J. Snower

120 P. T. Pereira

P. S. Martins

121
J. C. van Ours

122

D. Munich

J. Svejnar

K. Terrell

123 J. Hunt

124 R. T. Riphahn

125 F. Büchel

J. R. Frick

126 J. Fersterer

R. Winter-Ebmer

127 M. Karanassou

D. J. Snower

128

O. Ashenfelter

D. Ashmore

O. Deschênes

129 B. R. Chiswick

M. E. Hurst

130
G. Brunello
S. Comi
C. Lucifora

131 B. R. Chiswick

R. A. Hart

133

IAB Employment Subsample 1975-1995.

Opportunities for Analysis Provided by the

Anonymised Subsample

Improving Nurse Retention in the British National

Health Service: The Impact of Job Satisfaction on

Intentions to Quit

The Division of Labor and the Market for

Organizations

Does Education Reduce Wage Inequality?

Quantile Regressions Evidence from Fifteen

European Countries

Do Active Labor Market Policies Help Unemployed 4/6 3/00

Workers to Find and Keep Regular Jobs?

Returns to Human Capital under the Communist

Wage Grid and During the Transition to a Market

5

$2 / 00$

Economy

Why Do People Still Live in East Germany?

Rational Poverty or Poor Rationality? The Take-up 3

The Income Portfolio of Immigrants in Germany -

Who Gains from Income Re-Distribution?

Smoking, Discount Rates, and Returns to

Education

Characteristics of Unemployment Dynamics: The

Chain Reaction Approach

Do Unemployment Insurance Recipients Actively

Seek Work? Evidence From Randomized Trials in

Four U.S. States

The Employment, Unemployment and

Unemployment Compensation Benefits of

Immigrants

The Returns to Education in Italy: A New Look at the Evidence

Are Immigrants Favorably Self-Selected? An

Economic Analysis

Hours and Wages in the Depression: British $7 \quad 3 / 00$ Engineering, 1926-1938

Paid and Unpaid Overtime Working in Germany and 1

R. A. Hart

O. Hübler the UK 
134 A. D. Kugler

G. Saint-Paul

135 A. Barrett

P. J. O'Connell

136 M. Bräuninger

M. Pannenberg

137 J.-St. Pischke

138 J. Zweimüller

R. Winter-Ebmer

139 R. A. Hart

Y. Ma

140 G. Brunello

S. Comi

141 R. Hujer

M. Wellner

142 J. J. Dolado

F. Felgueroso

J. F. Jimeno

143 P. J. Luke

M. E. Schaffer

144 G. Saint-Paul

145 M.-S. Yun

146 T. K. Bauer

J. P. Haisken-DeNew

147 M. Belot

J. C. van Ours

148 L. Goerke

149 R. Lalive

J. C. van Ours

J. Zweimüller

150 J. DiNardo

K. F. Hallock

J.-St. Pischke

151 M. Ward
Hiring and Firing Costs, Adverse Selection and

Long-term Unemployment

Is There a Wage Premium for Returning Irish

Migrants?

Unemployment and Productivity Growth: An

Empirical Analysis within the Augmented Solow Model

Continuous Training in Germany

$3 / 00$

Firm-specific Training: Consequences for Job Mobility

Wages, Hours and Human Capital over the

Life Cycle

Education and Earnings Growth: Evidence from 11

European Countries

The Effects of Public Sector Sponsored Training on Individual Employment Performance in East Germany

Explaining Youth Labor Market Problems in Spain: 3 Crowding-Out, Institutions, or Technology Shifts?

$4 / 00$

Wage Determination in Russia: An Econometric Investigation

Flexibility vs. Rigidity: Does Spain have the worst of 1 both Worlds?

Decomposition Analysis for a Binary Choice Model 7

$4 / 00$

Employer Learning and the Returns to Schooling

5

$4 / 00$

Does the Recent Success of Some OECD

Countries in Lowering their Unemployment Rates

Lie in the Clever Design of their Labour Market

Reforms?

Employment Effects of Labour Taxation in an Efficiency Wage Model with Alternative Budget Constraints and Time Horizons

The Impact of Active Labor Market Programs and Benefit Entitlement Rules on the Duration of Unemployment

Unions and the Labor Market for Managers 
J. F. Jimeno

153 A. S. Kalwij

M. Gregory

154 M. Gerfin

M. Lechner

155 J. Hansen

156 C. Dustmann

F. Fabbri

157 P. Apps

R. Rees

158 A. Björklund

T. Eriksson

M. Jäntti

O. Raaum

E. Österbacka

159 P.- J. Jost

M. Kräkel

160 M. Lofstrom

161 V. Gimpelson

D. Treisman

G. Monusova

162 C. Dustmann

M. E. Rochina-

Barrachina

163 R. A. Hart

Y. Ma

164 M. A. Shields

S. Wheatley Price

165

P. J. Pedersen

166 Z. MacDonald

M. A. Shields

167 A. Barrett

J. FitzGerald

B. Nolan

168 G. S. Epstein

A. L. Hillman
State: An Appraisal

Overtime Hours in Great Britain over the Period 3

1975-1999: A Panel Data Analysis

Microeconometric Evaluation of the Active Labour 6

$5 / 00$

Market Policy in Switzerland

The Duration of Immigrants' Unemployment Spells: $\quad 1 / 3$

Evidence from Sweden

Language Proficiency and Labour Market Per- 1

formance of Immigrants in the UK

Household Production, Full Consumption and $\quad 7$

the Costs of Children

Brother Correlations in Earnings in Denmark, 5

Finland, Norway and Sweden Compared to the

United States

Preemptive Behavior in Sequential Tournaments

5

$5 / 00$

A Comparison of the Human Capital and Signaling Models: The Case of the Self-Employed and the 5 Increase in the Schooling Premium in the 1980's

Public Employment and Redistributive Politics: 4 Evidence from Russia's Regions

Selection Correction in Panel Data Models: An 6 Application to Labour Supply and Wages

Why do Firms Pay an Overtime Premium?

5

$6 / 00$

Racial Harassment, Job Satisfaction and Intentions

5

$6 / 00$ to Quit:

Immigration in a High Unemployment Economy: 1 The Recent Danish Experience

The Impact of Alcohol Consumption on Occupa- 5 tional Attainment in England

Earnings Inequality, Returns to Education and 5 Immigration into Ireland

Social Harmony at the Boundaries of the Welfare 3 State: Immigrants and Social Transfers 
Wages and the Demand for Health - A Life Cycle Analysis

Reforming the Financial Incentives of the Welfare

Self-Employment and Earnings among High-

Skilled Immigrants in the United States

Industrial Relations and the Wage Differentials

between Skilled and Unskilled Blue-Collar

Workers within Establishments: An Empirical

Analysis with Data of Manufacturing Firms

Immigrant Adjustment in Israel: Literacy and

178 R. Euwals M. Ward

179 E. Wasmer

P. Weil

Fluency in Hebrew and Earnings

The Renumeration of British Academics

The Macroeconomics of Labor and Credit Market Imperfections

180 T. K. Bauer

I. N. Gang

Sibling Rivalry in Educational Attainment: 
A. Zaidi

193 A. Kunze

194 A. Newell

F. Pastore

Absolute Risk Aversion and the Returns to Education

The Determination of Wages and the Gender Wage Gap: A Survey

Rational Migration Policy Should Tolerate Non- 